\title{
Boundary conditions for the Middle Miocene Climate Transition (MMCT v1.0)
}

\author{
Amanda Frigola ${ }^{1}$, Matthias Prange ${ }^{1,2}$, and Michael Schulz ${ }^{1,2}$ \\ ${ }^{1}$ MARUM Center for Marine Environmental Sciences, University of Bremen, 28359 Bremen, Germany \\ ${ }^{2}$ Faculty of Geosciences, University of Bremen, 28359 Bremen, Germany \\ Correspondence: Amanda Frigola (afrigola@marum.de)
}

Received: 12 July 2017 - Discussion started: 18 September 2017

Revised: 7 March 2018 - Accepted: 14 March 2018 - Published: 24 April 2018

\begin{abstract}
The Middle Miocene Climate Transition was characterized by major Antarctic ice sheet expansion and global cooling during the interval $\sim 15-13$ Ma. Here we present two sets of boundary conditions for global general circulation models characterizing the periods before (Middle Miocene Climatic Optimum; MMCO) and after (Middle Miocene Glaciation; MMG) the transition. These boundary conditions include Middle Miocene global topography, bathymetry, and vegetation. Additionally, Antarctic ice volume and geometry, sea level, and atmospheric $\mathrm{CO}_{2}$ concentration estimates for the MMCO and the MMG are reviewed. The MMCO and MMG boundary conditions have been successfully applied to the Community Climate System Model version 3 (CCSM3) to provide evidence of their suitability for global climate modeling. The boundary-condition files are available for use as input in a wide variety of global climate models and constitute a valuable tool for modeling studies with a focus on the Middle Miocene.
\end{abstract}

\section{Introduction}

The Middle Miocene (ca. 16-11.6 Ma) was marked by important changes in global climate. The first stage of this time period, the Middle Miocene Climatic Optimum (MMCO), was characterized by warm conditions, comparable to those of the late Oligocene. Although global climate remained warmer than present day during the whole Miocene (Pound et al., 2012), an important climate transition associated with major Antarctic ice sheet expansion and global cooling took place between $\sim 15$ and $13 \mathrm{Ma}$, the so called Middle Miocene Climate Transition (MMCT). Major evidence for this transi- tion is the increase in $\delta^{18} \mathrm{O}$ shown in benthic foraminiferal records (e.g., Lear et al., 2010; Shevenell et al., 2008; Holbourn et al., 2005).

An increase in benthic foraminiferal $\delta^{18} \mathrm{O}$ reflects either an increase in global ice volume, a decrease in bottom water temperature (BWT), or a combination of both. Different studies using benthic foraminiferal $\mathrm{Mg} / \mathrm{Ca}$ ratios (an independent proxy for BWT) to separate the global ice volume from the BWT signal in the benthic foraminiferal $\delta^{18} \mathrm{O}$ records conclude that both an increase in global ice volume and a decrease in BWT occurred during the MMCT, though global ice volume was the main part $(65-85 \%)$ in the benthic $\delta^{18} \mathrm{O}$ signal (Lear et al., 2010, 2000; Shevenell et al., 2008).

$\mathrm{Mg} / \mathrm{Ca}$ studies indicate that the cooling of bottom waters across the MMCT was within a range of $\sim 0.5$ to $\sim 3{ }^{\circ} \mathrm{C}$ (Lear et al., 2010, 2000; Shevenell et al., 2008; Billups and Schrag, 2002, 2003).

Studies by Kominz et al. (2008) and Haq et al. (1987), based on backstripping techniques, and John et al. (2011), combining backstripping techniques with benthic foraminiferal $\delta^{18} \mathrm{O}$, indicate an important eustatic sea level fall across the MMCT (see Sect. 3), providing further evidence of ice sheet expansion. Lewis et al. (2007) present data from glacial deposits in Southern Victoria Land (East Antarctica) showing local ice sheet expansion at different time intervals between $\sim 13.85$ and $\sim 12.44 \mathrm{Ma}$. They state that this ice sheet expansion was preceded by significant atmospheric cooling, with glacial deposits showing evidence of a permanent shift from wet to cold in the thermal regime of local glaciers at $\sim 13.94 \mathrm{Ma}$. Levy et al. (2016) analyze data from the ANDRILL-2A drill site, situated in the western Ross Sea, $\sim 30 \mathrm{~km}$ off the coast of Southern Victoria 
Land. The ANDRILL record presents two unconformities spanning the intervals $\sim 15.8$ to $\sim 14.6$ and $\sim 14.4 \mathrm{Ma}$ to the Late Miocene. These unconformities are interpreted to be caused by local episodes of grounded ice advance eroding material at the site at different times within those two intervals. A global compilation of paleobotanical data by Pound et al. (2012) shows cooling and/or drying in some mid-latitude areas across the MMCT, suggesting that this transition did not only affect high latitudes.

The causes for the MMCT are a matter of debate. Suggested driving mechanisms for this transition include a drop in atmospheric $p \mathrm{CO}_{2}$, changes in ocean circulation and water masses driven by ocean gateways reconfiguration, and/or orbitally triggered atmospheric heat and moisture transport variations (Flower and Kennett, 1994; Holbourn et al., 2007, 2005). Langebroek et al. (2010), for example, using an isotope enabled ice sheet-climate model forced with a $p \mathrm{CO}_{2}$ decrease and varying time-dependent orbital parameters, modeled an increase in $\delta^{18} \mathrm{O}$ of seawater in good agreement with published MMCT estimates.

Our aim is to assemble Middle Miocene boundary conditions for global coupled general circulation models (GCMs), setting up an improved basis to investigate the MMCT from a modeling perspective. The boundary conditions include global topography, bathymetry, and vegetation for the Middle Miocene (see Supplement). Besides, Antarctic ice volume and geometry, sea level, and atmospheric $\mathrm{CO}_{2}$ concentration estimates for the periods before (Middle Miocene Climatic Optimum, MMCO) and after (Middle Miocene Glaciation, MMG) the MMCT are reviewed and their uncertainties are discussed. The global topography and bathymetry presented here are mainly based on the Middle Miocene reconstruction by Herold et al. (2008), which has been used in previous modeling studies (e.g., Herold et al., 2012, 2011; Krapp and Jungclaus, 2011). However, we implement some important modifications with regard to Antarctic ice sheet geometry, sea level, and configuration of the Southeast Asian and Panama seaways taking into account recent reconstructions. Vegetation cover used in most previous Middle Miocene modeling studies with prescribed vegetation was mainly based on Wolfe's (1985) Early Miocene reconstruction (e.g., Herold et al., 2011; Tong et al., 2009; You et al., 2009). Here, Middle Miocene data (Pound et al., 2012; Morley, 2011) have also been used.

Our study provides the core boundary conditions required to set up GCM experiments with a Middle Miocene configuration. With this configuration as a starting point, a wide variety of sensitivity studies with a focus on the Middle Miocene and its global climate transition can be performed. Despite the relatively low availability of Middle Miocene data, our assemblage of boundary conditions reflects the state of the art in Miocene research. Results from two model runs with the Community Climate System Model version 3 (CCSM3) (Collins et al., 2006) using the MMCO and MMG boundary conditions are also presented.

\section{Antarctic ice sheet geometry}

Giving quantitative Antarctic ice volume estimates for the MMCT is challenging at best. Most sediment core studies present ice volume estimates in units of seawater $\delta^{18} \mathrm{O}$. Backstripping methods provide sea level rather than ice volume estimates. More direct Antarctic ice volume estimates can be derived from modeling studies (Gasson et al., 2016; Langebroek et al., 2009; Oerlemans, 2004).

Gasson et al. (2016) performed a series of simulations with an ice sheet model asynchronously coupled to a regional climate model and an isotope-enabled GCM using Middle Miocene paleogeography and a range of atmospheric $\mathrm{CO}_{2}$ concentrations and extreme astronomical configurations. The study tested two different Antarctic bedrock topography scenarios: one scenario with present-day bedrock topography and the other with an approximate Middle Miocene bedrock topography. For a range of $\mathrm{CO}_{2}$ concentrations between 500 and 280 ppmv and changing orbital parameters ("warm astronomical configuration" versus "cold astronomical configuration") an increase in Antarctic ice volume from 11.5 (17.2) million $\mathrm{km}^{3}$ in the warmer climate to 26.7 (35.5) million $\mathrm{km}^{3}$ in the colder climate was simulated using modern (Middle Miocene) bedrock topography.

Langebroek et al. (2009) used a coupled ice sheet-climate model forced by atmospheric $\mathrm{CO}_{2}$ and insolation changes to reconstruct Antarctic ice volume across the MMCT. The experiment with the best fit to $\delta^{18} \mathrm{O}$ data was forced by a $\mathrm{CO}_{2}$ drop from 640 to $590 \mathrm{ppmv}$ at around $\sim 13.9 \mathrm{Ma}$ and simulates an increase in Antarctic ice volume from $\sim 6$ million to $\sim 24$ million $\mathrm{km}^{3}$ across the MMCT.

Oerlemans (2004) derived Cenozoic Antarctic ice volume variations by means of a simple quasi-analytical ice sheet model and two different $\delta^{18} \mathrm{O}$ benthic foraminiferal records. The ice sheet model approximates Antarctic ice volume as a function of deep sea temperature. Using the Zachos et al. (2001) benthic foraminiferal $\delta^{18} \mathrm{O}$ data, an ice volume increase from $\sim 5$ million to $\sim 23$ million $\mathrm{km}^{3}$ for the MMCT was obtained, while for the $\delta^{18} \mathrm{O}$ curve by Miller et al. (1987) the increase was only from $\sim 15$ million to $\sim 23$ million $\mathrm{km}^{3}$.

Based on the studies by Oerlemans (2004) and Langebroek et al. (2009), we set a total Antarctic ice sheet volume of 23 million $\mathrm{km}^{3}$ for the MMG (Table 1; Fig. 1). This value is within the range of published estimates, although smaller than the values estimated by Gasson et al. (2016) in their "cold climate" experiments with extreme astronomical configuration. For the MMCO we assumed a total Antarctic ice sheet volume of 6 million $\mathrm{km}^{3}$. This volume estimate is in good agreement with the values given by Langebroek et al. (2009) and Oerlemans (2004), although significantly lower than Gasson et al. (2016) (see above).

In this study, we opted for using ice sheet model-derived Antarctic topography estimates from an earlier Cenozoic time period with similar Antarctic ice volume. These data were kindly provided by David Pollard (Pennsylvania State 
MMCO

(a)

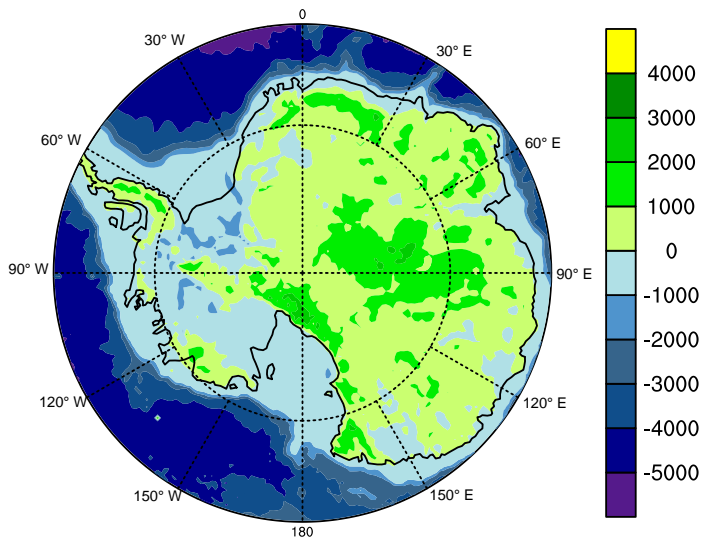

(c)

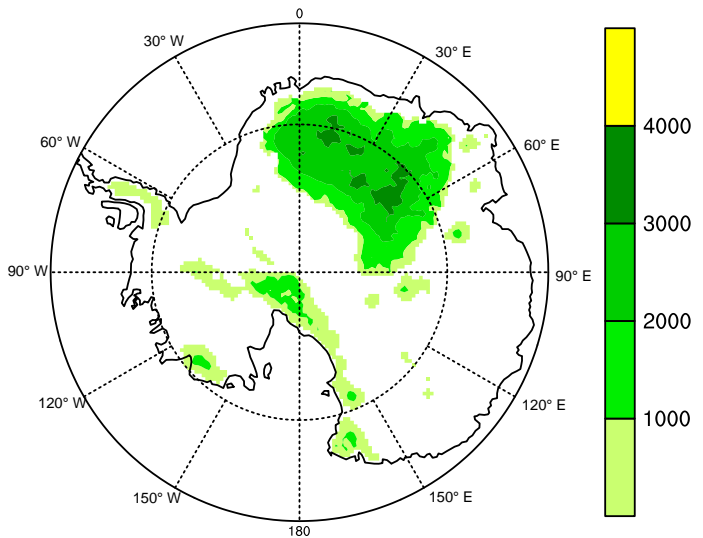

(e)

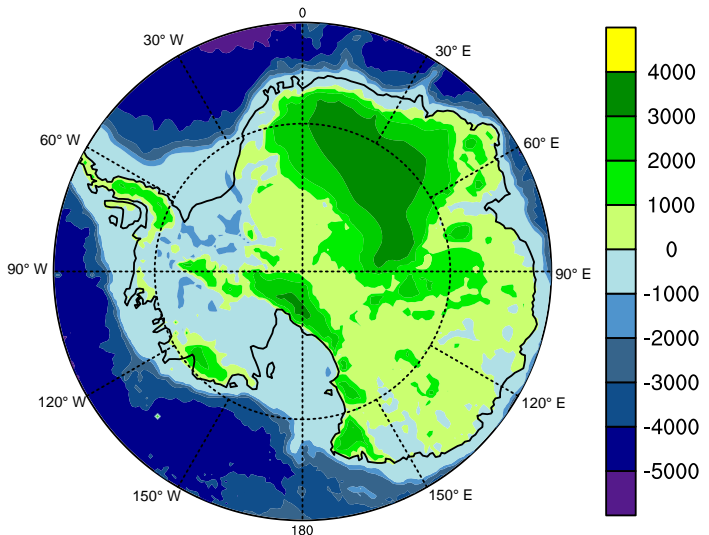

MMG

(b)

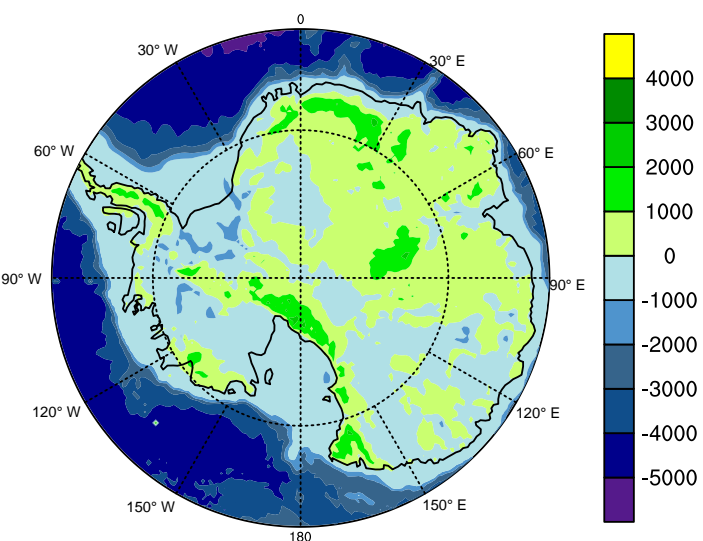

(d)

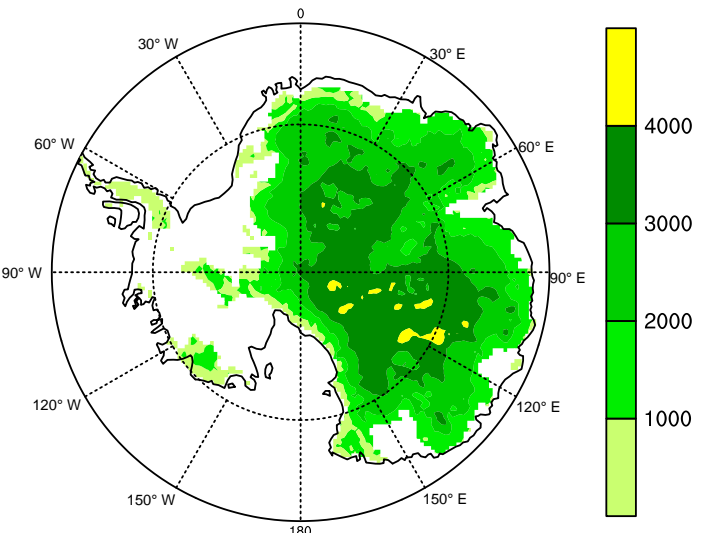

(f)

(m)

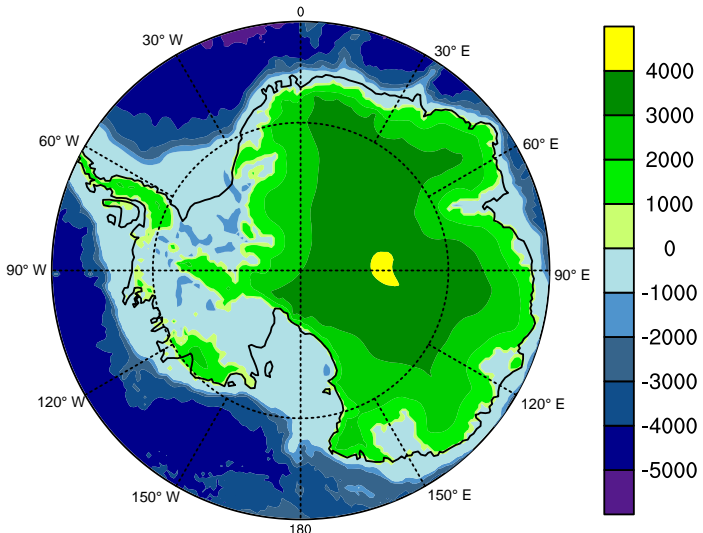

Figure 1. Reconstruction of Antarctica for the Middle Miocene Climatic Optimum (MMCO) and the Middle Miocene Glaciation (MMG): $(\mathbf{a}, \mathbf{b})$ bedrock elevation; (c, d) ice thickness; $(\mathbf{e}, \mathbf{f})$ surface elevation (bedrock elevation + ice thickness), in meters. Black lines represent present-day coastline. Data from David Pollard. 
Table 1. Summary of boundary conditions for the Middle Miocene Climatic Optimum (MMCO) and the Middle Miocene Glaciation (MMG).

\begin{tabular}{lll}
\hline & MMCO & MMG \\
\hline Antarctic ice sheet volume & 6 million $\mathrm{km}^{3}$ & 23 million $\mathrm{km}^{3}$ \\
Sea level & $48 \mathrm{~m}$ higher than present day & $5 \mathrm{~m}$ higher than present day \\
Atmospheric $\mathrm{CO}_{2}$ & $400 \mathrm{ppmv}$ & $200 \mathrm{ppmv}$ \\
concentration & & \\
Global topography/bathymetry & $\begin{array}{l}\text { mainly Herold et al. (2008) with modifications } \\
\text { for tropical seaways (Hall, 2012; Montes et al., }\end{array}$ & $\begin{array}{l}\text { same as MMCO, but with global sea level } \\
\text { reduced by } 43 \text { m and an expanded Antarctic }\end{array}$ \\
& $\begin{array}{l}\text { 2012) and the Antarctic ice sheet } \\
\text { mainly Pound et al. (2012) with gaps filled } \\
\text { according to Wolfe (1985) and Morley (2011); } \\
\text { ice and tundra in Antarctica }\end{array}$ & $\begin{array}{l}\text { same as MMCO, but with tundra removed in } \\
\text { Antica }\end{array}$ \\
& &
\end{tabular}

University) and correspond to the Oligocene Oi-1 glaciation event. They were obtained with a model version close to that described in Pollard and DeConto (2012), but with no marine ice physics, so that any floating ice is immediately removed. The bedrock-elevation boundary conditions used in that run are from the modern ALBMAPv1 dataset (Le Brocq et al., 2010). Climate forcing is obtained from a matrix of GCM climates for various orbits, $\mathrm{CO}_{2}$ levels, and ice sizes (Pollard, 2010). Insolation is based on Laskar et al. (2004). The run is $12 \mathrm{Myr}$ long, nominally from "37 to $25 \mathrm{Ma}$ ". The configuration we used to represent MMCO conditions corresponds to $34.8 \mathrm{Ma}$; the one representing MMG conditions, to $33 \mathrm{Ma}$.

In the MMG configuration the whole of East Antarctica is covered with a single ice sheet meanwhile the islands of West Antarctica contain only some small ice caps, with no marine-based ice sheets. In the MMCO configuration Antarctica is only partially glaciated, with an ice cap covering the Transantarctic Mountains and another one over eastern East Antarctica. Again, West Antarctica contains only some ice caps, with no marine-based ice sheets (Fig. 1). We deem the ice configurations from the Oi-1 glaciation run appropriate for the MMCT as they match total ice volumes of 23 million $\mathrm{km}^{3}$ for the MMG and of 6 million $\mathrm{km}^{3}$ for the MMCO, values that are within the range of published ice volume estimates for the MMG and MMCO, respectively. Besides, there is little to link Pollard's run to a specific time period (except for the Laskar orbits). The configurations of Oerlemans (2004) and Langebroek et al. (2009) were discarded in our study because they are rather simple (no twodimensional representation of the Antarctic ice sheet is available from those studies). The configuration of Gasson et al. (2016) could be considered in future sensitivity studies, since uncertainties in ice volume estimates are high. Nevertheless, the distribution of ice in our study is comparable to that in Gasson et al. (2016): for the MMG, a continentalscale ice sheet exists in East Antarctica with ice thicknesses of $\sim 3000-4000 \mathrm{~m}$, although in West Antarctica there is less ice in Pollard's data; for the MMCO, the ice sheets occupy similar positions, although they are less extensive in Pollard's data.
The ice volume values of 6 million and 23 million $\mathrm{km}^{3}$ for the MMCO and the MMG, respectively, imply an increase of 17 million $\mathrm{km}^{3}$ across the MMCT. This value is within the range of published estimates and in reasonable agreement with the values by Langebroek et al. (2009), Oerlemans (2004) as well as Gasson et al. (2016) (see above).

Although some studies suggest ice would have been present in the Northern Hemisphere during the Middle Miocene (Thiede et al., 2011; DeConto et al., 2008), little is known about its temporal and spatial distribution. In view of the lack of concrete data, Northern Hemisphere ice was neglected in the current study.

\section{Sea level change across the MMCT}

For the sake of coherency within the current set of Middle Miocene boundary conditions, we opted for a sea level change across the MMCT that is consistent with our ice sheet volume estimates for the MMCO and MMG (see previous section), presuming that global sea level change across the MMCT time interval was dominated by glacio-eustasy. The ice sheet volume estimates were converted into sea level equivalents according to the following equation (Langebroek et al., 2009):

$S_{\text {eq }}=\left(\rho_{\text {ice }} \times V_{\text {ice }}\right) /\left(\rho_{\text {water }} \times A_{0}\right)$,

where $S_{\text {eq }}$ represents sea level equivalent, $V_{\text {ice }}$ ice sheet volume, $\rho_{\text {ice }}$ density of ice, $\rho_{\text {water }}$ density of water, and $A_{0}$ ocean surface area. With $\rho_{\text {ice }}=910 \mathrm{~kg} \mathrm{~m}^{-3}, \rho_{\text {water }}=1000 \mathrm{~kg} \mathrm{~m}^{-3}$ and $A_{0}=360.5$ million $\mathrm{km}^{2}$ (present day approx.), values of 16 and $59 \mathrm{~m}$ for the MMCO and the MMG respectively were obtained (as in Langebroek et al., 2009), and thus a sea level fall across the MMCT of $43 \mathrm{~m}$ (Table 1).

Lear et al. (2010) combine $\mathrm{Mg} / \mathrm{Ca}$ and $\mathrm{Li} / \mathrm{Ca}$ ratios to estimate BWT at ODP Site 761 across the MMCT. Seawater $\delta^{18} \mathrm{O}$ is then derived by extracting the BWT signal from the $\delta^{18} \mathrm{O}$ signal from the same site. The data suggest an increase in seawater $\delta^{18} \mathrm{O}$ of $0.6 \%$ between 15.3 and $12.5 \mathrm{Ma}$. This value is converted into a sea level fall equivalent us- 
ing the Pleistocene calibration of $0.08-0.11 \%$ o per $10 \mathrm{~m}$ sea level (Fairbanks and Matthews, 1978), obtaining an eustatic sea level drop of $\sim 55-75 \mathrm{~m}$ between 15.3 and $12.5 \mathrm{Ma}$.

De Boer et al. (2010) used one-dimensional ice sheet models and benthic foraminiferal $\delta^{18} \mathrm{O}$ data (Zachos et al., 2008) to derive eustatic sea level and BWT changes over the last $35 \mathrm{Ma}$. In their approach, surface air temperature has been derived through an inverse procedure from the benthic $\delta^{18} \mathrm{O}$ record. The study suggests a sea level drop of $\sim 40 \mathrm{~m}$ between 15 and $12 \mathrm{Ma}$, i.e., from $\sim 55$ to $\sim 15 \mathrm{~m}$ above present day.

Kominz et al. (2008) combine data from different boreholes collected from the New Jersey and Delaware Coastal Plains to derive sea level for the last $108 \mathrm{Ma}$ through backstripping. They register a $\sim 20 \mathrm{~m}$ sea level fall between $\sim 14.2$ and $\sim 12.8 \mathrm{Ma}$, i.e., from $\sim 25$ to $\sim 5 \mathrm{~m}$ above present day. These data contain some unconformities however, implying that the actual amplitude of the MMCT sea level drop could indeed have been higher than proposed there.

John et al. (2011) estimate Middle Miocene sea level changes based on backstripping and benthic foraminiferal oxygen isotope data. Backstripping is applied to sediment core data from the Marion Plateau, offshore northeastern Australia, obtaining a range of sea level variations which is then further constrained using benthic foraminiferal $\delta^{18} \mathrm{O}$ data from Zachos et al. (2001). John et al. (2011) suggest a 53-69 m sea level fall between 16.5 and 13.9 Ma. Unfortunately, their analyses are limited to this time interval.

Our sea level fall estimate of $43 \mathrm{~m}$ across the MMCT is consistent with Langebroek et al. (2009) $(\sim 43 \mathrm{~m})$ and in good agreement with the study by De Boer et al. (2010) $(\sim 40 \mathrm{~m})$, although somewhat larger than the values by Gasson et al. (2016) $(\sim 30-36 \mathrm{~m})$ and considerably higher than the estimate from Kominz et al. (2008) ( $20 \mathrm{~m}$ of sea level fall). By contrast, John et al. (2011) suggest a higher amplitude of sea level drop ( 53-69 m), similar to the $\sim 55-75 \mathrm{~m}$ by Lear et al. (2010). As such, our assumption of a $43 \mathrm{~m}$ sea level fall lies well within the range of published estimates.

\section{Atmospheric $\mathrm{CO}_{2}$ concentration}

Numerous studies based on both marine (Foster et al., 2012; Pearson and Palmer, 2000; Tripati et al., 2009; Pagani et al., 2005) and terrestrial (Retallack, 2009; Kürschner et al., 2008) proxies reconstructing Middle Miocene atmospheric $\mathrm{CO}_{2}$ levels are present in the literature. However, the range of published estimates is rather wide. The difference in the $\mathrm{CO}_{2}$ estimates between the various studies most likely arises from method-related uncertainties and/or the relatively coarse temporal resolution of some of the datasets. Based on planktonic foraminiferal boron isotopic data, Foster et al. (2012) suggest atmospheric $p \mathrm{CO}_{2}$ values reaching a maximum of $\sim 390 \mathrm{ppmv}$ at $\sim 15.8 \mathrm{Ma}$ and decreasing to $\sim 200$ ppmv by $\sim 12 \mathrm{Ma}$. Pearson and
Palmer (2000), using the same method, obtain a maximum value of $\sim 300 \mathrm{ppmv}$ at $\sim 16.2 \mathrm{Ma}$ followed by a decline to $\sim 140 \mathrm{ppmv}$ by $\sim 14.7 \mathrm{Ma}$ and an increase to $\sim 225 \mathrm{ppmv}$ by $\sim 11.4$ Ma. Tripati et al. (2009), by means of surfacedwelling foraminiferal boron / calcium ratios, obtain a maximum value of $\sim 430 \mathrm{ppmv}$ at $\sim 15.1$ Ma followed by a decrease to $\sim 340 \mathrm{ppmv}$ by $\sim 12 \mathrm{Ma}$ and down to $\sim 230 \mathrm{ppmv}$ by $\sim 9.9 \mathrm{Ma}$. Retallack (2009), based on carbon isotopes of pedogenic carbonate, suggests atmospheric $p \mathrm{CO}_{2}$ levels reaching a maximum of $\sim 850 \mathrm{ppmv}$ at $\sim 15.6 \mathrm{Ma}$, dropping down to $\sim 115 \mathrm{ppmv}$ by $\sim 14.6 \mathrm{Ma}$ and increasing to $\sim 430 \mathrm{ppmv}$ by $\sim 12.8 \mathrm{Ma}$. Kürschner et al. (2008) used stomatal-density data from fossil leaves to support $p \mathrm{CO}_{2}$ values reaching a maximum over $\sim 400-500 \mathrm{ppmv}$ at $\sim 15.5 \mathrm{Ma}$, decreasing to $\sim 280 \mathrm{ppmv}$ by $\sim 14 \mathrm{Ma}$ and increasing to $\sim 340 \mathrm{ppmv}$ by $\sim 12 \mathrm{Ma}$. By contrast, Pagani et al. (2005), using a method based on alkenone carbon isotopes, obtain $p \mathrm{CO}_{2}$ values oscillating between $\sim 200$ and $\sim 300$ ppmv across the Middle Miocene.

We chose atmospheric $\mathrm{CO}_{2}$ concentrations of 400 and 200 ppmv to represent the MMCO and the MMG respectively (Table 1). Although somewhat arbitrary, these values are within the range of published estimates. The 400 ppmv MMCO value is in favorable agreement with Foster et al. (2012) $(\sim 392 \mathrm{ppmv}$ at $\sim 15.8 \mathrm{Ma})$ and Tripati et al. (2009) ( $\sim 430$ ppmv at $\sim 15.1 \mathrm{Ma})$, although higher than Pearson et al. $(2000)(\sim 300 \mathrm{ppmv}$ at $\sim 16.2 \mathrm{Ma})$ and Pagani et al. (2005) $(\sim 300 \mathrm{ppmv}$ at $\sim 15 \mathrm{Ma})$, and lower than Kürschner et al. (2008) $(>\sim 400-500$ ppmv at $\sim 15.5 \mathrm{Ma})$ and Retallack (2009) $(\sim 852 \mathrm{ppmv}$ at $\sim 15.6 \mathrm{Ma})$ maxima. The $400 \mathrm{ppmv}$ estimate is also in good agreement with the most recent alkenone- and boron isotope-based $p \mathrm{CO}_{2}$ reconstructions for the MMCO by Zhang et al. (2013) and Greenop et al. (2014). The 200 ppmv MMG estimate is in good agreement with Foster et al. (2012) $(\sim 200 \mathrm{ppmv}$ at $\sim 12 \mathrm{Ma})$ and Pagani et al. (2005) $(\sim 200 \mathrm{ppmv}$ at $\sim 13 \mathrm{Ma})$, although higher than Pearson et al. $(2000)(\sim 140 \mathrm{ppmv}$ at $\sim 14.7 \mathrm{Ma})$ and Retallack (2009) ( $\sim 116 \mathrm{ppmv}$ at $\sim 14.6 \mathrm{Ma})$, and lower than Tripati et al. (2009) $(\sim 340 \mathrm{ppmv}$ at $\sim 12 \mathrm{Ma})$ and Kürschner et al. (2008) $(\sim 280 \mathrm{ppmv}$ at $\sim 14 \mathrm{Ma})$ minima.

\section{Global topography and bathymetry}

We present two different global Middle Miocene topography/bathymetries here, characterizing the MMCO and the MMG periods (Fig. 2, Table 1, Supplement). Both global topography/bathymetries are mainly based on the $2^{\circ} \times 2^{\circ}$ reconstruction of Herold et al. (2008), although some important modifications, which will be described below, were applied to their original dataset. To reconstruct paleogeography and paleotopography Herold et al. (2008) used a global plate rotation model and geological data. Ocean depth was reconstructed by applying an age-depth relationship to a global Middle Miocene isochron map. Sediment thickness and large 


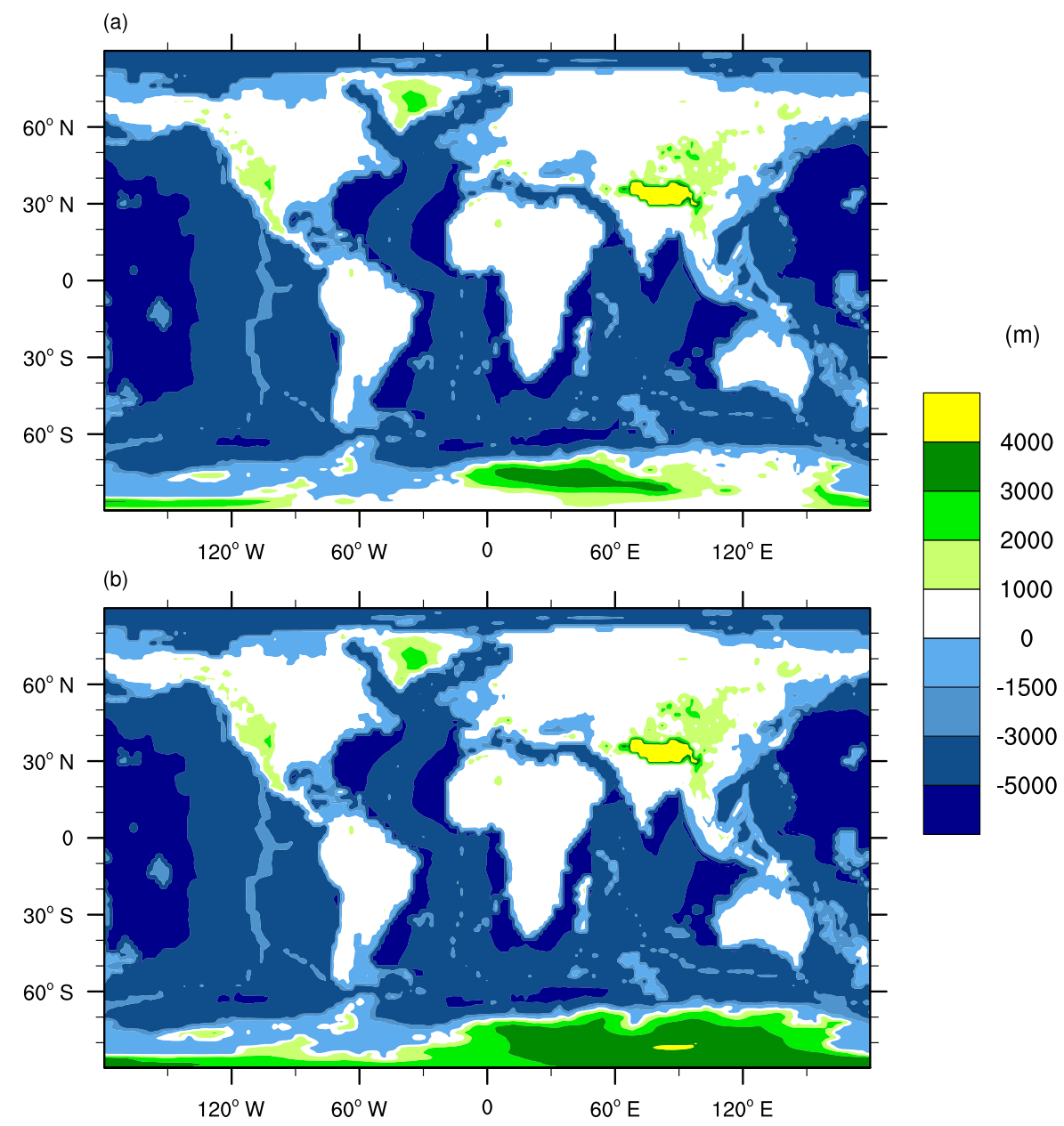

Figure 2. Topography/bathymetry reconstruction for the (a) MMCO and the (b) MMG.

igneous provinces were also considered in the reconstruction of ocean depth.

In Herold et al. (2008), the Andes and the Tibetan Plateau were set with estimated Early to Middle Miocene elevations. The Rocky Mountains and the East African topography were reduced to 75 and $25 \%$ of their current elevation, respectively. The Greenland topography was also reduced, representing ice-free conditions. The Bering Strait was closed and the Hudson Bay removed. Unlike Herold et al. (2008), who assumed the Tethys seaway closed, we decided to leave the seaway open (based on a modification by the authors of Herold et al., 2008; Nicholas Herold, personal communication, 2011). According to Rögl (1999), the Tethys passage closed during the Burdigalian (20.44-15.97 Ma), re-opened temporary during the Langhian (15.97-13.65 Ma) and closed again during the Serravallian (13.65-11.62 Ma). Also based on Rögl (1999), the Paratethys was intermittently connected and disconnected from the global ocean during the Burdigalian to Serravallian interval. In Herold et al. (2008), as in our reconstruction, the Paratethys is connected to the global ocean. In view of the variable configuration of the Tethys/Paratethys across the Middle Miocene, it would be recommendable to test different Tethys/Paratethys configurations when performing Middle Miocene experiments with GCMs, although such testing can be limited by model constraints: seas disconnected from the global ocean can produce freshwater imbalance in GCMs and narrow ocean passages require high-resolution ocean grids to allow ocean flux calculation (Rosenbloom et al., 2011). Some studies, indeed, suggest that the Tethys passage closure might have played a role in Middle Miocene atmosphere and ocean circulation patterns (Ramstein et al., 1997; Hamon et al., 2013).

Additional important modifications were applied to the original dataset of Herold et al. (2008) regarding Antarctic ice sheet geometry, sea level, and configuration of the Southeast Asian and Panama seaways (see discussion below in Sect. 5.1-5.4) (Fig. 3). 
(m)

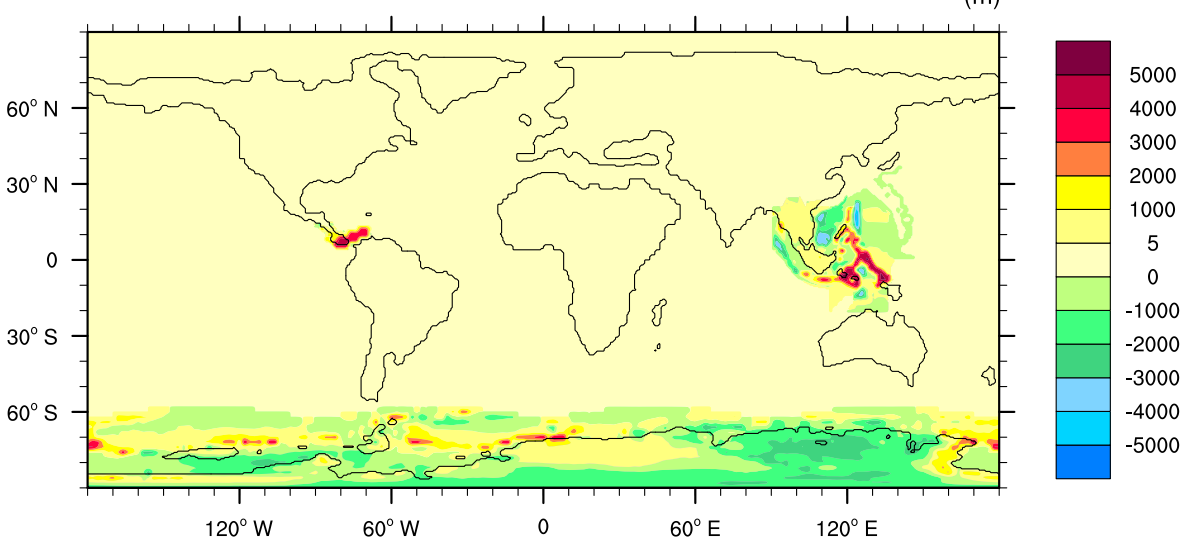

Figure 3. Difference between MMCO and the topography/bathymetry by Herold et al. (2008), in meters. Sea level is $4 \mathrm{~m}$ higher in the MMCO dataset (Sect. 5.2), the Indonesian Throughflow barriers are shallower (Sect. 5.3), the Panama seaway is narrower (Sect. 5.4), and the Antarctic topography/bathymetry is based on David Pollard's data (Sect. 5.1) and consistent with MMCO ice volume estimates.

\subsection{Antarctica}

Antarctic ice sheet geometry was modified for consistency with our ice sheet volume estimates for the MMCO and MMG (see Sect. 2). In the high southern latitudes, from 60 to $90^{\circ} \mathrm{S}$, the original topography/bathymetry from Herold et al. (2008) was replaced by the Antarctic topography/bathymetry data from David Pollard described above (Fig. 1e, f).

\subsection{Sea level}

Sea level was adjusted to $\sim 48$ and $\sim 5 \mathrm{~m}$ above present day for the MMCO and MMG, respectively (Table 1). These values were derived from our sea level equivalent estimates (see above) by assuming $64 \mathrm{~m}$ of present-day sea level equivalent. This present-day estimate is in good agreement with Vaughan et al. (2013) (58.3 $\mathrm{m}$ for the Antarctic ice sheet and $7.36 \mathrm{~m}$ for the Greenland ice sheet). The adjustments were applied taking into account that sea level is $\sim 52 \mathrm{~m}$ above present day in Herold et al. (2008) (Nicholas Herold, personal communication, 2011) and at present-day level in David Pollard's data. We note that the sea level adjustment of $4 \mathrm{~m}$ (i.e., $48 \mathrm{~m}$ above present day instead of $52 \mathrm{~m}$ ) with respect to Herold et al. (2008) for the MMCO is minor and has virtually no effect in common global climate models at low spatial resolution.

\subsection{Southeast Asian gateway}

Southeast Asian paleogeography was modified based on Hall's (2012) reconstruction constrained at $15 \mathrm{Ma}$ (Fig. 4). Hall's data, available as a georeferenced image, were converted into grid format using ArcGIS. Qualitative height/depth values were assigned to the different geographic features: $\sim 2800 \mathrm{~m}$ for volcanoes, $\sim 1000 \mathrm{~m}$ for highlands, $\sim 250 \mathrm{~m}$ for land, $\sim-22 \mathrm{~m}$ for carbonate plat-

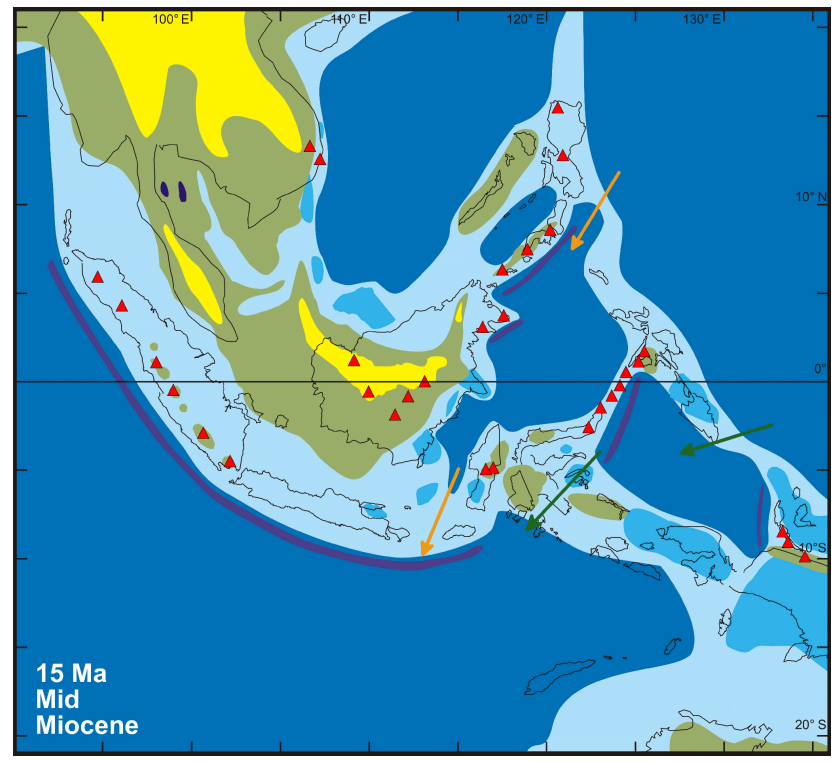

Figure 4. Paleogeographic reconstruction of Southeast Asia for 15 Ma from Hall (2012). Geographic features: volcanoes in red (triangles), highlands in yellow, land in green, carbonate platforms in blue, shallow sea in light blue, deep sea in dark blue, and trenches in violet. Figure courtesy of Robert Hall (Royal Holloway, University of London). Arrows represent Middle Miocene postulated ocean paths across the Indonesian archipelago and are based on Kuhnt et al. (2004). Eastern paths shown in green, western paths in orange.

forms, $\sim-200 \mathrm{~m}$ for shallow sea, $<-4000 \mathrm{~m}$ for deep sea, and $\sim-5500 \mathrm{~m}$ for trenches. After embedding the data into the MMCO global dataset, minor manual smoothing was applied at the margins of the embedded region. Here, shallow bays were removed and single, shallow grid points surrounded by much deeper grid points were deepened to the 
adjacent depth. In total, these modifications affected $\sim 0.5 \%$ of the total number of grid points.

Based on the depth values assigned to the different geographic features in the Southeast Asia reconstruction, the deepest connection between the Indian and the Pacific oceans would be only $\sim 200 \mathrm{~m}$ deep. This is probably too shallow, since in the Middle Miocene the Indonesian gateway was likely open for both surface and intermediate water (Kuhnt et al., 2004). Deep water passages were therefore added to the MMCO global topography/bathymetry dataset, based on the postulated Middle Miocene ocean paths across the Indonesian archipelago described in Kuhnt et al. (2004) (Fig. 4). The depth values assigned to these passages are shallower than those of the present-day passages (Kuhnt et al., 2004). Based on an educated guess the depths of the two eastern passages were set to $800 \mathrm{~m}$, shallower than those of the present-day eastern Lifamatola $(\sim 1940 \mathrm{~m})$ and Timor ( 1300-1450 m) passages (Gordon et al., 2003). The northwestern passage was assigned a depth of $1000 \mathrm{~m}$, shallower than that of the present-day northwestern Sangihe Ridge sill ( $\sim 1350 \mathrm{~m}$ ) (Gordon et al., 2003). The depth of the southwestern passage was set to $600 \mathrm{~m}$, slightly shallower than that of the present-day southwestern Dewakang sill $(680 \mathrm{~m})$ (Gordon et al., 2003). Assigned widths are somewhat arbitrary. The eastern passages were both given a width of $\sim 150 \mathrm{~km}$ ( $\sim 3$ grid cells), and the northwestern and southwestern passages a width of $\sim 350 \mathrm{~km}(\sim 6$ grid cells $)$ and $\sim 220 \mathrm{~km}$ $(\sim 4$ grid cells) respectively.

For the MMG, the same Southeast Asia topography/bathymetry reconstruction was used as for the MMCO after applying a $\sim 43 \mathrm{~m}$ sea level change, in correspondence with our MMCT sea level fall estimate (see above).

\subsection{Panama seaway}

Also the Panama seaway was modified such that substantial differences exist compared to the original dataset of Herold et al. (2008). Montes et al. (2012) suggest a narrow Panama strait already existed by the Early Miocene, with a width of $\sim 200 \mathrm{~km}$. Therefore, the width of the seaway was set accordingly in our paleogeographic dataset, together with a depth of $\sim 1000 \mathrm{~m}$ which reflects Panama sill reconstructions for the Middle Miocene by Duque-Caro (1990).

\section{Global vegetation}

The current MMCO and MMG global vegetation reconstructions (Fig. 5, Supplement) were based on Pound et al. (2012), Wolfe (1985) and Morley (2011). The study by Pound et al. (2012) includes global vegetation reconstructions for the Langhian (15.97-13.65 Ma) (approximately the end of the MMCO) and the Serravallian (13.65-11.61 Ma) (roughly coincident with the MMG). Wolfe's (1985) study contains an Early Miocene global vegetation reconstruction. The recon- structions from Pound et al. (2012) and Wolfe (1985) are the only Early/Middle Miocene global reconstructions. Morley's (2011) Middle Miocene reconstruction focuses only on the distribution of tropical forests.

The study by Pound et al. (2012), based on paleobotanical evidence from 617 Middle/Late Miocene data locations, constituted the main source of global vegetation data for our MMCO and MMG boundary conditions. Morley's (2011) study added some detail to the current reconstructions in the tropical areas. Wolfe's (1985) Early Miocene data were used in regions where the Middle Miocene reconstructions by Pound et al. (2012) and Morley (2011) had scarce data coverage and also to characterize the vegetation patterns of the main mountain ranges.

The above studies use different nomenclatures to classify the different types of vegetation. Pound et al. (2012) use the BIOME4 classification (Kaplan, 2001), while Wolfe (1985) uses the classification scheme described in Wolfe (1979). Here, we coded the data in the land surface model (LSM) (Bonan, 1996) biome classification scheme. All biome names in this study referring to the classifications in the studies by Pound et al. (2012), Wolfe (1985), and Morley (2011) are italicized. LSM biome names are set in quotation marks. Table 2 shows how the data from Pound et al. (2012), Wolfe (1985) and Morley (2011) were converted into the LSM scheme. However, we note that the correspondence between biomes of different schemes is not always optimal (see notes in Table 2). The warm-temperate evergreen broadleaf and mixed forest BIOME4 biome was converted into the LSM scheme as "warm mixed forest". The "warm mixed forest" LSM biome represents a mixture of needleleaf evergreen temperate trees and broadleaf deciduous temperate trees, meanwhile the warm-temperate evergreen broadleaf and mixed forest BIOME4 biome represents either (a) temperate broadleaf evergreen trees alone, or (b) cool conifer trees mixed with temperate broadleaf evergreen trees, or (c) temperate deciduous trees mixed with either temperate broadleaf evergreen trees or cool conifer trees. The conversion is suboptimal because no broadleaf evergreen temperate trees are present in the "warm mixed forest" LSM biome. Nevertheless, the "warm mixed forest" still constitutes a fair representation of the warm-temperate evergreen broadleaf and mixed forest BIOME4 biome. In case a more precise representation in the LSM scheme of the warm-temperate evergreen broadleaf and mixed forest BIOME4 biome was required, the LSM scheme could be modified by adding a new biome containing the exact specific plant types present in the warm-temperate evergreen broadleaf and mixed forest BIOME4 biome described above (a similar approach is used in Herold et al., 2010). Note also that Table 2 does not contain all the biomes present in the different vegetation schemes, but only the ones effectively used in the current reconstructions.

Neither Pound et al. (2012), nor Wolfe (1985), or Morley (2011) provide the data in a gridded format, a requirement for the use in GCMs. According to the geographical 


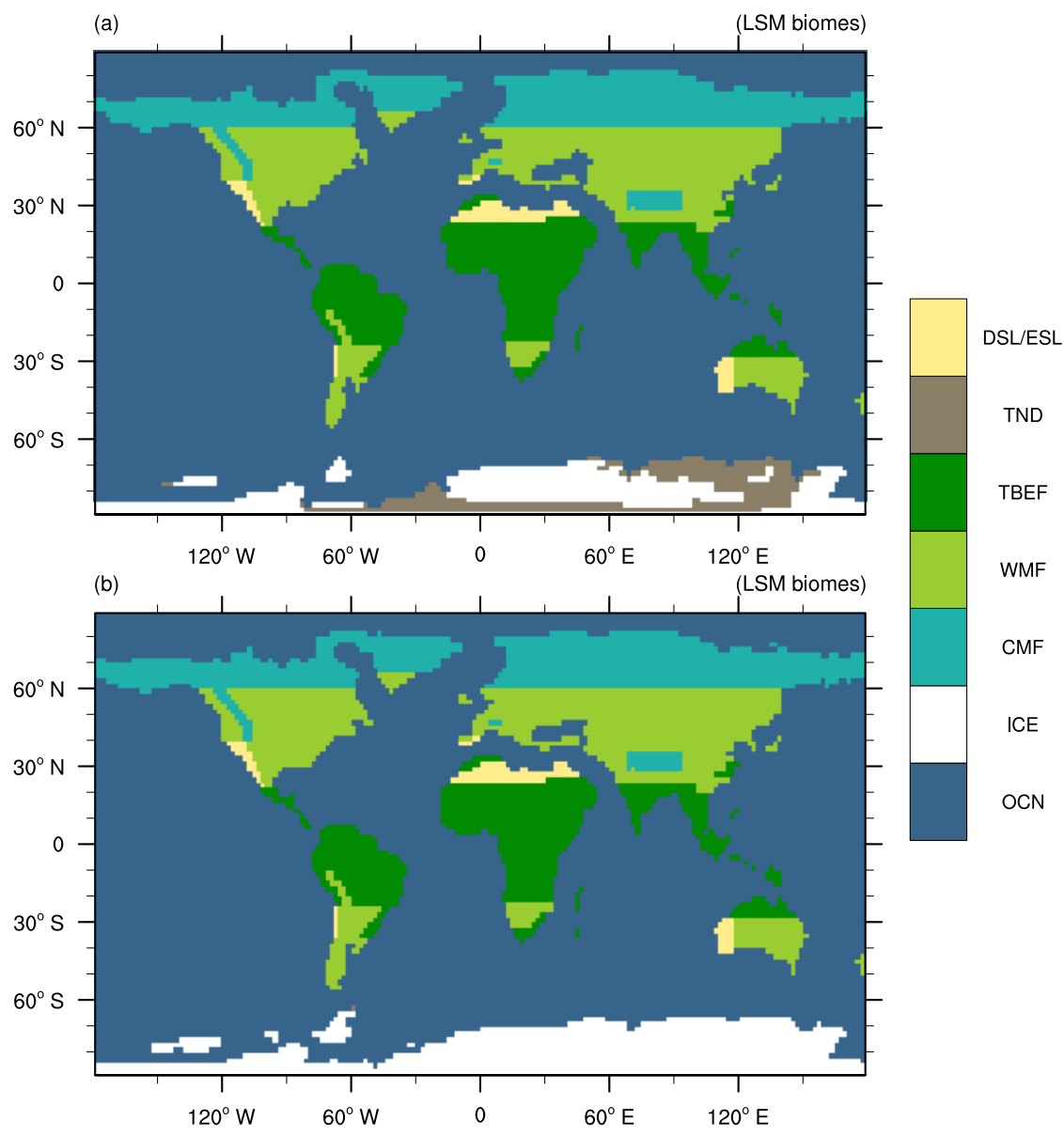

Figure 5. Vegetation reconstruction for the (a) MMCO and the (b) MMG. Colors represent LSM biomes: DSL is deciduous shrubland, ESL is evergreen shrubland, TND is tundra, TBEF is tropical broadleaf evergreen forest, WMF is warm mixed forest, CMF is cool mixed forest, ICE is land ice, and OCN is ocean.

coordinates specified in those reconstructions, we merged the data on a $2^{\circ} \times 2^{\circ}$ latitude/longitude grid for MMCO and MMG, giving preference to the Middle Miocene reconstructions by Pound et al. (2012) and Morley (2011). The Early Miocene reconstruction of Wolfe (1985) was only used at locations where no data are available from the other two reconstructions. An exception are the Alps, Rocky Mountains, Himalayas and Tibetan Plateau, where we used the information from Wolfe (1985). In the regions where the reconstructions from Pound et al. (2012) and Morley (2011) conflicted with each other, the reconstruction of Pound et al. (2012) was used, except for locations where the latter was less well constrained by proxy information than Morley (2011).

The MMCO and the MMG global vegetation reconstructions presented here solely differ in terms of "tundra" distribution on Antarctica (Fig. 5). In both reconstructions "tundra" was assigned to the ice-free regions of Antarctica, taking account of the MMCO and MMG ice sheet geometries (Fig. 1c, d). Assuming the "tundra" distribution to be the only difference in terms of vegetation between the MMCO and the MMG is a simplification. Part of the warm-temperate evergreen broadleaf and mixed forest ("warm mixed forest" in the LSM scheme) present in the middle latitudes during the Langhian was replaced by "cooler and/or drier temperate biomes" during the Serravallian (Pound et al., 2012). This cooling and/or drying trend was observed for example in areas like western North America or Europe (Pound et al., 2012). Additionally, by the Serravallian, in the tropics, some drier biomes than those present there during the Langhian had started to spread (e.g., in Southeast Asia) (Pound et al., 2012). Nevertheless, the Langhian and Serravallian global vegetation patterns were "similar" in comparison with the "markedly different biome pattern of the Tortonian from that of the Serravallian" (see Figs. 5 and 6 in Pound et al., 2012), which justifies our simplified approach. However, for studies with a specific focus on vegetation-triggered climatic changes across the MMCT, the user could modify our MMG vegetation dataset (LSM scheme) as follows (based on Pound et al., 2012): (a) in the mid-latitudes of western North America, the "warm mixed forest" between 40 and $50^{\circ} \mathrm{N}$ could 
Table 2. Conversion of vegetation types to the LSM vegetation scheme.

\begin{tabular}{|c|c|}
\hline BIOME4 & LSM \\
\hline $\begin{array}{l}\text { Tropical evergreen broadleaf forest } \\
\text { Tropical deciduous broadleaf forest and woodland } \\
\text { Warm-temperate evergreen broadleaf and mixed forest } \\
\text { Cool-temperate mixed forest } \\
\text { Tropical savanna } \\
\text { Temperate xerophytic shrubland } \\
\text { Temperate deciduous broadleaf savanna } \\
\text { Temperate grassland } \\
\text { Low- and high-shrub tundra } \\
\text { Prostrate dwarf-shrub tundra } \\
\text { Ice }\end{array}$ & $\begin{array}{l}\text { Tropical broadleaf evergreen forest } \\
\text { Tropical broadleaf deciduous forest } \\
\text { Warm mixed forest }{ }^{1} \\
\text { Cool mixed forest }{ }^{2} \\
\text { Savanna } \\
\text { Evergreen shrub land or deciduous shrub land } \\
\text { Deciduous shrub land } \\
\text { Cool grassland } \\
\text { Tundra } \\
\text { Tundra } \\
\text { Land ice }\end{array}$ \\
\hline \multicolumn{2}{|l|}{ Wolfe's (1979) classification } \\
\hline $\begin{array}{l}\text { Mixed coniferous forest } \\
\text { Tropical rain forest } \\
\text { Paratropical rain forest }\end{array}$ & $\begin{array}{l}\text { Cool mixed forest } \\
\text { Tropical broadleaf evergreen forest } \\
\text { Tropical broadleaf evergreen forest }\end{array}$ \\
\hline \multicolumn{2}{|l|}{ Morley's (2011) classification } \\
\hline $\begin{array}{l}\text { Megathermal rain forest } \\
\text { Monsoonal megathermal forest }\end{array}$ & $\begin{array}{l}\text { Tropical broadleaf evergreen forest } \\
\text { Tropical broadleaf deciduous forest }\end{array}$ \\
\hline $\begin{array}{l}1 \text { The warm-temperate evergreen broadleaf and mixed forest may contair } \\
\text { deciduous trees. The warm mixed forest contains needleleaf evergreen tre } \\
\text { deciduous trees in the cool-temperate mixed forest are temperate, meanw } \\
\text { coniferous forest is mainly needleleaf evergreen, but broadleaf trees are a } \\
\text { mixed forest is formed by needleleaf evergreens and broadleaf deciduous } \\
\text { forest is mainly broadleaf evergreen, but it may contain some broadleaf }\end{array}$ & $\begin{array}{l}\text { roadleaf evergreen trees, needleleaf evergreen trees and } \\
\text { and deciduous trees, but not broadleaf evergreen trees. } \\
\text { e the ones in the cool mixed forest } \text { are boreal. }^{3} \text { The mixed } \\
\text { present. These can be deciduous or evergreen. The cool } \\
\text { roadleaf evergreens are not present. }{ }^{4} \text { The paratropical rain } \\
\text { iduous and conifers. }\end{array}$ \\
\hline
\end{tabular}

be partly replaced with "warm broadleaf deciduous forest". Also a "cool mixed forest" could be added in the same region at $42^{\circ} \mathrm{N}$; (b) in Europe, some "deciduous shrub land" could be added to the "warm mixed forest" in southern France between $42.5-44^{\circ} \mathrm{N}$ and $6-9^{\circ} \mathrm{E}$, and also between $38-47^{\circ} \mathrm{N}$ and $29-36^{\circ} \mathrm{E}$.

We are aware that the Middle Miocene global vegetation reconstructions presented here are rather coarse. Still, we consider it a fair characterization of the MMCO and MMG global vegetation distributions. Grosso modo, the present reconstructions are characterized by "cool mixed forest" at high northern latitudes, predominantly "warm mixed forest" at middle latitudes, "tropical broadleaf evergreen forest" in the tropics, and "tundra" in the ice-free regions of Antarctica (Fig. 5). Compared to pre-industrial (PI), the vegetation of the Middle Miocene represents a warmer and wetter climate. In the Northern Hemisphere high latitudes, forests are warmer, with no forest tundra or tundra present. The midlatitudes present warmer and wetter biomes, with e.g., less shrubland-type biomes. The tropics are wetter, with less savanna and less grasses. There is no evidence of a desert in either northern Africa (Sahara) or Central Asia. In the Southern Hemisphere high latitudes, tundra is present at the MMCO and disappears after the Antarctic ice sheet expansion at the MMG (Pound et al., 2012; Bonan et al., 2002). For a higher degree of detail, in GCMs including a dynamic vegetation component, our Middle Miocene vegetation datasets could be used to initialize the vegetation model. Another valid approach would be using the output from an offline vegetation model as boundary condition (e.g., the ones described in Henrot et al., 2017), although here our aim was to provide vegetation boundary conditions based on paleobotanical data. A detailed discussion of the vegetation patterns we assigned to each region can be found in the Appendix A.

\section{Testing the boundary conditions with CCSM3}

To provide evidence of the suitability of our input data for global climate modeling, we applied the boundary conditions to CCSM3. CCSM3 is a fully coupled GCM consisting of components representing atmosphere, ocean, land, and sea ice (Collins et al., 2006). A total of three runs were performed: two Miocene runs (MMCO and MMG) and a preindustrial control run (PI). The atmosphere horizontal grid employed in the PI run, T42, is a Gaussian grid with 64 points in latitude and 128 points in longitude $\left(\sim 2.8^{\circ}\right.$ resolution). The notation T42 refers to the spectral truncation level. The land and atmosphere models share the same horizontal grid. The ocean horizontal grid, $\times 1$, is a dipole grid with 384 points in latitude and 320 points in longitude. The zonal resolution of the ocean horizontal grid is $\sim 1^{\circ}$, the mean 

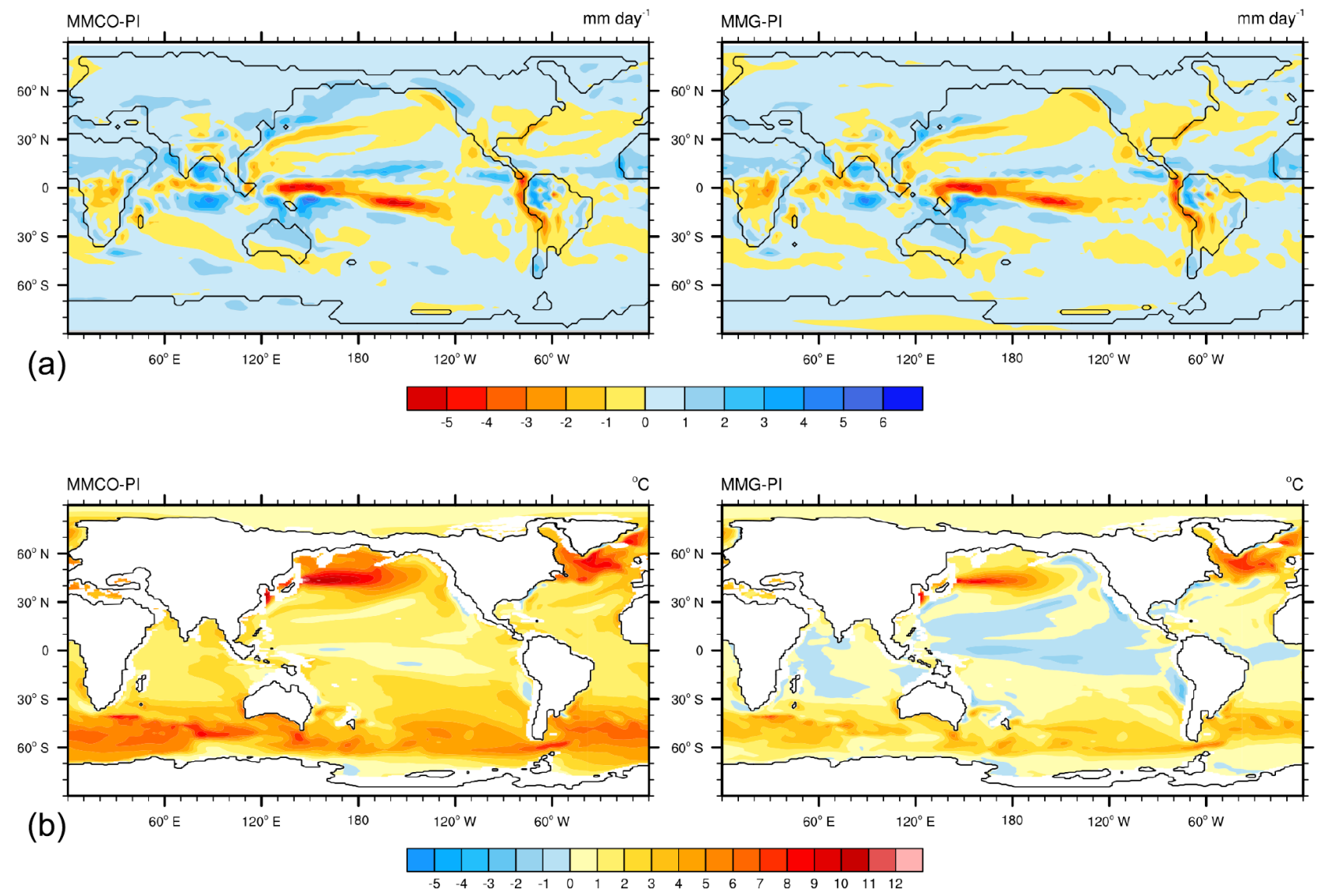

Figure 6. Precipitation $\left(\mathrm{mm}_{\text {day }}{ }^{-1}\right)$ (a) and sea-surface temperature $\left({ }^{\circ} \mathrm{C}\right)(\mathbf{b})$ differences between $\mathrm{MMCO}$ and $\mathrm{MMG}$ experiments, and PI, respectively.

meridional resolution is $\sim 0.5^{\circ}$, refined around the equator $\left(\sim 0.3^{\circ}\right)$. The notation $\times 1$ refers to the nominal zonal resolution. The ocean and sea-ice components share the same horizontal grid. The atmosphere and ocean vertical grids have 26 and 40 vertical levels, respectively. This model grid configuration is known as T42 $\times 1$. For the Miocene runs the same grids as for the PI run were used, except for the horizontal ocean (and sea-ice) grid, for which a customized grid was used. This grid is also a dipole grid with 384 points in latitude and 320 points in longitude, although extended to $\sim 87^{\circ} \mathrm{S}$ (instead of $\sim 79^{\circ} \mathrm{S}$ ) in order to accommodate the changes in the bathymetry off West Antarctica.

In the Miocene topography/bathymetry datasets West Antarctica is for the most part below sea level, with ocean reaching down to $\sim 85^{\circ} \mathrm{S}$. If the standard CCSM3 grid had been used for the Miocene experiments, the ocean region between $\sim 79$ and $85^{\circ} \mathrm{S}$ would not have been taken into account in the ocean circulation simulations. The Miocene grid was created from scratch using the CCSM3 setup tools described in Rosenbloom et al. (2011) and it is defined by the following parameters: dyeq $=0.25$ (meridional grid spacing at the equator, in degrees), $\mathrm{dsig}=20$ (Gaussian $e$-folding scale at equator), and jcon $=45$ (rows of constant merid-
Table 3. Summary of atmospheric composition, solar constant, and orbital configuration for the CCSM3 test experiments. PI values are according to Otto-Bliesner et al. (2006). The orbital configuration represents $1950 \mathrm{AD}$ values. $\mathrm{PD}$ is present day.

\begin{tabular}{lrrr}
\hline Experiment & PI & MMCO & MMG \\
\hline $\mathrm{CO}_{2}$ & $280 \mathrm{ppmv}$ & $400 \mathrm{ppmv}$ & $200 \mathrm{ppmv}$ \\
\cline { 2 - 4 } $\mathrm{CH}_{4}$ & $760 \mathrm{ppbv}$ & & \\
$\mathrm{N}_{2} \mathrm{O}$ & $270 \mathrm{ppbv}$ & & \\
$\mathrm{CFC}$ 's & 0 & & \\
$\mathrm{O}_{3}$ & $1870 \mathrm{AD}$ & & \\
Sulfate aerosols & $1870 \mathrm{AD}$ & & \\
Dust and sea salt & $\mathrm{PD}$ & same as PI \\
Carbonaceous aerosols & $30 \% \mathrm{of} \mathrm{PD}^{-2}$ & & \\
Solar constant & $1365 \mathrm{~W} \mathrm{~m}^{-2}$ & & \\
Eccentricity & 0.016724 & & \\
Obliquity & $23.446^{\circ}$ & \\
Precession & $102.04^{\circ}$ & \\
\end{tabular}

ional grid spacing at poles). In some areas the Miocene grid presents a slightly coarser resolution than the PI grid, since both grids have the same number of grid points and the 


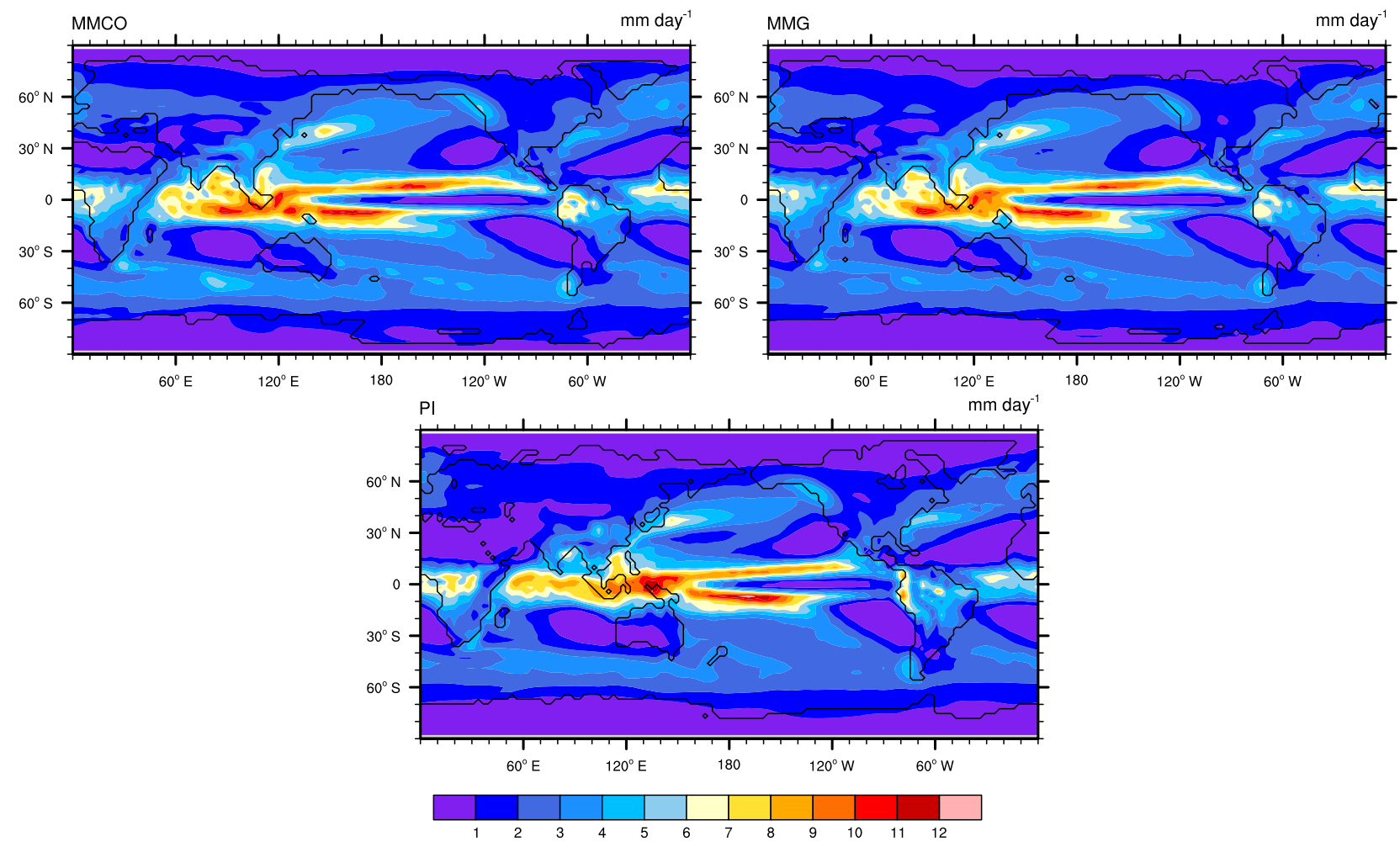

Figure 7. Precipitation for MMCO, MMG, and PI, in mm day ${ }^{-1}$.

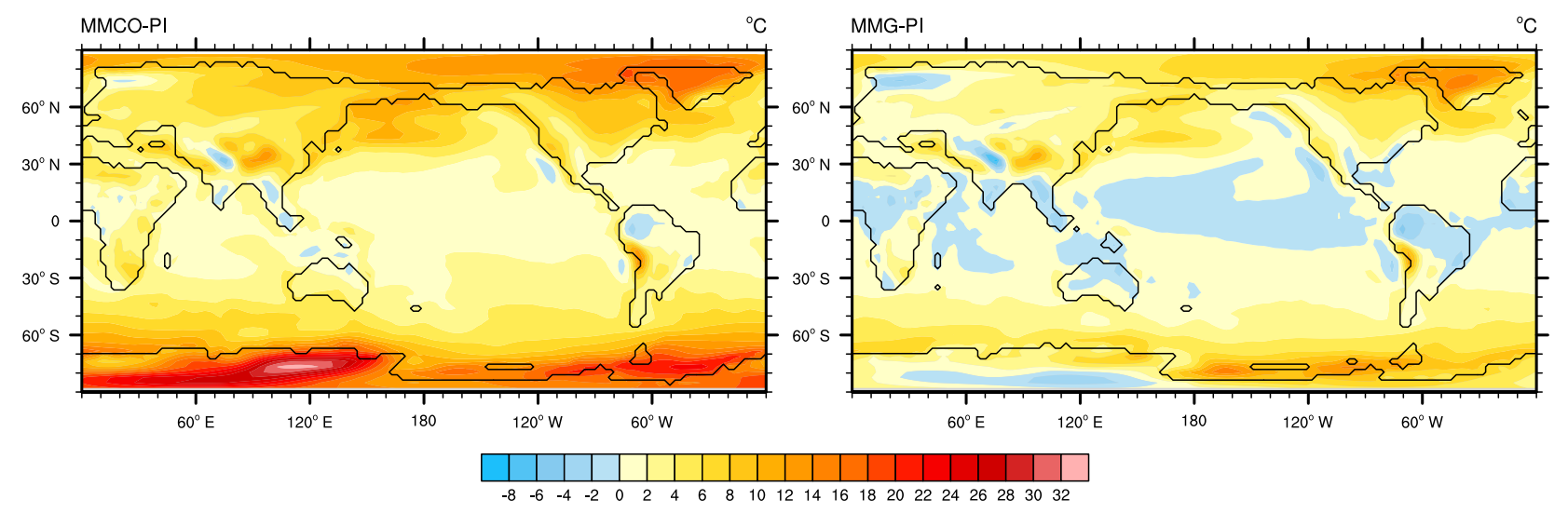

Figure 8. Surface air temperature differences (at $2 \mathrm{~m}$ height) (in ${ }^{\circ} \mathrm{C}$ ) between $\mathrm{MMCO}$ and $\mathrm{MMG}$ experiments, and PI, respectively.

Miocene grid reaches further south than the PI grid. In order to be able to compare the Miocene and PI results, the PI model output data were regridded onto the Miocene grid using the patch recovery method (http://www.ncl.ucar.edu/ Applications/ESMF.shtml), which gives better approximations than the bilinear method. We do not think interpolation has any significant effect on the results.

For the PI run, well-mixed greenhouse gases, ozone distribution, aerosols, solar constant and orbital configuration were set to PI following Otto-Bliesner et al. (2006). The boundary conditions summarized in Table 1 were used for the
Miocene experiments; well-mixed greenhouse gases, ozone, aerosols, solar constant and orbital configuration were kept the same as in PI, except for $\mathrm{CO}_{2}$ (Table 3). The PI experiment was branched from the NCAR CCSM3 1870 CE control run and integrated another 150 years (850 years in total). The Miocene experiments were integrated for a total of 1500 years. The last 100 years of each simulation were used for the analysis. The temperature trends in the deep ocean (at $4-5 \mathrm{~km}$ depth) are $<0.14,0.15$, and $0.17^{\circ} \mathrm{C} / 100$ years in the PI, MMCO, and MMG cases, respectively. At that same depth range, the salinity trends are $<0.01,0.007$, 
and $0.01 \mathrm{psu} / 100$ years for PI, MMCO, and MMG, respectively. These values represent quasi-equilibrium conditions and we consider them sufficiently small for the focus of this study. The global mean precipitation rates are 3.00, 2.86, and $2.72 \mathrm{~mm} \mathrm{day}^{-1}$ for the MMCO, MMG, and PI experiments, respectively. Some patterns distinguishing the Miocene runs from the PI run include lower precipitation rates during the Miocene along the northwest coast of South America $\left(15^{\circ} \mathrm{S}-\right.$ $10^{\circ} \mathrm{N}$ ) (up to $3-4 \mathrm{~mm} \mathrm{day}^{-1}$ lower) (Figs. 6, 7), although reaching further inland. In Central Africa, between $20^{\circ} \mathrm{S}-$ $5^{\circ} \mathrm{N}$, the results show values also up to $3-4 \mathrm{~mm} \mathrm{day}^{-1}$ lower than PI, which might be related to the reduced Miocene East African topography (Jung et al., 2016). An intensification of the precipitation occurs in the Indian Ocean, compared to PI, with the Intertropical Convergence Zone (ITCZ) reaching further north at $\sim 90^{\circ} \mathrm{E}$ (Bay of Bengal). On the contrary, in the equatorial Pacific the PI run exhibits higher precipitation rates than the Miocene runs. These changes in the rain-belt patterns could be related to the different extent and distribution of ice sheets in both hemispheres. Other studies have already suggested that global ice sheets might have an effect on the ITCZ (Holbourn et al., 2010; Groeneveld et al., 2017). Other interesting patterns are the decrease in precipitation across the MMCT over the East African coast, between $0-20^{\circ} \mathrm{N}\left(0.5-2 \mathrm{~mm} \mathrm{day}^{-1}\right.$ lower), as well as the drying at high latitudes $\left(0-1 \mathrm{~mm} \mathrm{day}^{-1}\right)$. Regarding sea surface temperatures (SSTs) (Fig. 6), the highest values correspond to the MMCO experiment, with a mean global SST of $19.62^{\circ} \mathrm{C}$, followed by the MMG experiment $\left(18.04^{\circ} \mathrm{C}\right)$ and the PI experiment $\left(16.85^{\circ} \mathrm{C}\right)$. The decrease in SST across the MMCT is particularly evident in the southern high latitudes and the northern North Pacific (values up to $6-7{ }^{\circ} \mathrm{C}$ lower). When considering surface air temperatures (at $2 \mathrm{~m}$ height), our results show mean global values of $16.38,13.88$, and $12.16^{\circ} \mathrm{C}$ for the MMCO, MMG, and PI, respectively (Fig. 8). The modeled decrease in mean global surface air temperatures $\left(2.5^{\circ} \mathrm{C}\right)$ and $\mathrm{SSTs}\left(1.6^{\circ} \mathrm{C}\right)$ between MMCO $\left(\mathrm{CO}_{2}=400 \mathrm{ppmv}\right)$ and MMG $\left(\mathrm{CO}_{2}=200 \mathrm{ppmv}\right)$ is in good agreement with the CCSM3 climate sensitivity values suggested in Kiehl et al. (2006). Our global mean surface air temperature and precipitation values support the idea of a Middle Miocene climate warmer and wetter than PI, and a cooling and drying trend across the MMCT. $\mathrm{Mg} / \mathrm{Ca}$ data from ODP Hole 1171C on the South Tasman Rise indicate cooling of SSTs of $\sim 2{ }^{\circ} \mathrm{C}$ across the MMCT (Shevenell et al., 2004). This value is within our range of cooling estimates for the Southern Ocean. Knorr and Lohmanns' (2014) MMCT model results show a decrease of $3.1^{\circ} \mathrm{C}$ in global mean surface air temperature across the MMCT, a value slightly higher than our $2.5^{\circ} \mathrm{C}$ estimate. Although $\mathrm{CO}_{2}$ is lower in the MMG simulation than in the control run, SSTs are higher for MMG than for PI. Potential causes for a MMG climate warmer than PI are the lower extent of ice sheets (the Antarctic ice sheet is smaller and the Northern Hemisphere is free of ice sheets in the MMG run), and the different veg- etation cover (Knorr et al., 2011). However, unambiguously disentangling the effects of each of the different boundary conditions would require performing a series of sensitivity experiments, which is beyond the scope of the current study. Here our aim was testing the idoneity of the current boundary conditions as input data in GCMs for MMCO and MMG experiments.

\section{Concluding remarks}

The current study describes and provides a complete set of boundary conditions for GCMs characterizing the MMCO and the MMG periods. These boundary conditions include global topography, bathymetry, and vegetation, and have a particular focus on the Antarctic ice sheet and the Southeast Asian gateway. Besides, atmospheric $\mathrm{CO}_{2}$ concentrations and sea level estimates were reviewed in detail. Other GCM input data, which strongly depend on the technical details of individual GCMs, like river routing, were not discussed here, but can be constructed from the provided topographic datasets.

All data gathered in this study are available in the supplement, ready for use in GCMs. The compilation of boundary conditions for GCMs is time-consuming, especially when referring to deep time periods such as the Miocene. This assemblage of data can be used by the paleomodeling community as a base for a wide variety of Middle Miocene studies, particularly for those related to the MMCT. Output data from two global climate model experiments using these boundary conditions were briefly described here, in order to proof the suitability of the new sets of boundary conditions for modeling purposes.

Despite ongoing efforts, the Middle Miocene is still a period with scarce data availability and thus the Middle Miocene picture presented here is inevitably subject to large uncertainties. More data, improved methods and higher resolutions are required in order to improve the current boundary conditions and hence obtain more detailed and reliable model results.

Code and data availability. All the MMCO and MMG boundary conditions described above, as well as the CCSM3 model output files from the MMCO, MMG, and PI experiments, can be found in NetCDF format in the Supplement. The same data will be available in short time on PANGAEA - Data Publisher for Earth \& Environmental Science. The MMCO and MMG global topography/bathymetry data are available from the $0.5^{\circ} \times 0.5^{\circ}$ lat/long grid files mmco_topo_bathy_v1_0.nc and mmg_topo_bathy_v1_0.nc, respectively. The MMCO and MMG global vegetation data can be found in the $2^{\circ} \times 2^{\circ}$ lat/long grid files mmco_veg_v1_0.nc and mmg_veg_v1_0.nc, respectively. The CCSM3 output files are named MMCO_exp.nc, MMG_exp.nc, and PI_exp.nc, for MMCO, MMG, and PI, respectively. 


\section{Appendix A}

\section{A1 Europe}

The most widespread biome in the middle latitudes of Europe during the Langhian was the warm-temperate evergreen broadleaf and mixed forest ("warm mixed forest") (Pound et al., 2012). On the southern and eastern coast of Spain however, drier biomes such as temperate xerophytic shrubland ("evergreen shrub land"/“deciduous shrub land") or temperate deciduous broadleaf savanna ("deciduous shrub land") were present (Pound et al., 2012) (Fig. 5). The vegetation patterns of the Serravallian were similar to those of the Langhian. However, some drying and/or cooling occurred. In East Europe, for example, the data by Pound et al. (2012) indicate the emergence of temperate deciduous broadleaf savanna ("deciduous shrub land"). These drier and/or cooler biomes developed during the Serravallian were neglected for simplification in the current reconstructions.

Evidence for the Middle Miocene European high northern latitudes (above $60^{\circ} \mathrm{N}$ ) is missing in Pound et al. (2012). This region was painted with mixed coniferous forest ("cool mixed forest") (Fig. 5) in the current MMCO and MMG reconstructions based on Wolfe's (1985) Early Miocene data. We also filled the Alpine area with mixed coniferous forest (“cool mixed forest") according to Wolfe (1985).

\section{A2 Asia}

The Asian high northern latitudes were assigned "cool mixed forest" in the current MMCO and MMG reconstructions (Fig. 5). Pound et al. (2012) suggest cool-temperate mixed forest ("cool mixed forest") to have been the dominant biome in the eastern Asian high northern latitudes during the Middle Miocene. No data are provided for the western Asian high northern latitudes in Pound et al. (2012). Wolfe's (1985) reconstruction suggests two different vegetation patterns for the western Asian high northern latitudes during the Early Miocene, corresponding to north and south. For simplification, only the northern pattern, consisting of mixed coniferous forest ("cool mixed forest"), was considered in the current reconstructions.

The western Asian middle latitudes were filled with "warm mixed forest" (Fig. 5). Pound et al. (2012) propose a "south to north drying and cooling trend" for that region during the Middle Miocene, starting with warm-temperate evergreen broadleaf and mixed forest ("warm mixed forest") in the southern part and ending with temperate deciduous broadleaf savanna ("deciduous shrub land") in the northern part. For simplification, only the warm-temperate evergreen broadleaf and mixed forest ("warm mixed forest") was considered in our current MMCO and MMG boundary conditions.

The Himalayas and the Tibetan Plateau were assigned mixed coniferous forest ("cool mixed forest") based on Wolfe's (1985) reconstruction.
The eastern Asian middle latitudes were mainly populated by warm-temperate evergreen broadleaf and mixed forest ("warm mixed forest") during the Middle Miocene (Pound et al., 2012) (Fig. 5). Along the coast at $\sim 32^{\circ} \mathrm{N}$, there was a tropical evergreen broadleaf forest ("tropical broadleaf evergreen forest"), and west of $111^{\circ} \mathrm{E}$ a drier region containing biomes such as temperate xerophytic shrubland ("evergreen shrub land"/“deciduous shrub land") (Pound et al., 2012). This drier region was dismissed for simplification in our MMCO and MMG reconstructions.

Tropical evergreen broadleaf forest ("tropical broadleaf evergreen forest") was the dominant biome in India and Southeast Asia during the Middle Miocene (Pound et al., 2012) (Fig. 5).

\section{A3 Australia and New Zealand}

Tropical evergreen broadleaf forest ("tropical broadleaf evergreen forest") was present in northeast Australia during the Middle Miocene (Pound et al., 2012) (Fig. 5). Also in the east, but south of $28^{\circ} \mathrm{S}$, warm-temperate evergreen broadleaf and mixed forest ("warm mixed forest") was present (Pound et al., 2012).

In Pound et al. (2012) the description of Australia is limited to the east side. A line of megathermal rain forest ("tropical broadleaf evergreen forest") was assigned along the north coast in the current reconstructions based on Morley's (2011) Middle Miocene data.

Wolfe's (1985) Early Miocene reconstruction suggests the vegetation patterns of east Australia to be also representative for central Australia. Assuming this would still be valid during the Middle Miocene, the "warm mixed forest" assigned to east Australia in the current reconstructions, was extended to central Australia.

Wolfe's (1985) data further suggest similar vegetation patterns for west Australia and the southern coast of Spain during the Early Miocene. Assuming this analogy to be still valid during the Middle Miocene, west Australia was filled with "evergreen shrub land"/“deciduous shrub land", which is the vegetation assigned to the southern coast of Spain in the current MMCO and MMG reconstructions.

Warm-temperate evergreen broadleaf and mixed forest ("warm mixed forest") occupied New Zealand during the Middle Miocene (Pound et al., 2012) (Fig. 5).

\section{A4 Antarctica}

There is evidence for low- and high-shrub tundra and prostrate dwarf-shrub tundra ("tundra") at the Antarctic margins during the Langhian (Pound et al., 2012). By the Serravallian, practically no vegetation was present on Antarctica (Pound et al., 2012). In the current MMCO and MMG reconstructions "tundra" was assigned to the ice-free regions, in consistence with the ice sheet geometries described above (Fig. 5). 


\section{A5 Africa and the Arabian Peninsula}

Africa and the Arabian Peninsula have poor data coverage in Pound et al. (2012). Evidence from Pound et al. (2012) for the most northern part of Africa for the Middle Miocene is restricted to one site (in Tunisia), suggesting a warm-temperate evergreen broadleaf and mixed forest ("warm mixed forest"). That data site was dismissed in our current MMCO and MMG reconstructions, in view of the inappropriateness to extrapolate data from only one site to the whole surrounding region. Instead, the most northern part of Africa was set to "evergreen shrub land"/“deciduous shrub land" (Fig. 5). Wolfe's (1985) Early Miocene reconstruction suggests similar vegetation patterns for that region as for the southern coast of Spain. Assuming these two regions also kept similar vegetation patterns during the Middle Miocene, "evergreen shrub land" "/"deciduous shrub land", the vegetation assigned to the southern coast of Spain in the current MMCO and MMG reconstructions, was also assigned to the most northern part of Africa. Also a narrow belt of megathermal rain forest ("tropical broadleaf evergreen forest") was set along the northwest coast, in agreement with Morley's (2011) Middle Miocene reconstruction.

Madagascar was assigned megathermal rain forest ("tropical broadleaf evergreen forest"), following Morley (2011). Also based on Morley's (2011) reconstruction, an area of megathermal rain forest ("tropical broadleaf evergreen forest") was defined along the south and southeast coast of southern Africa. Pound et al. (2012) suggest that drier tropical biomes, e.g., tropical savanna ("savanna"), were present close to the southern coast of southern Africa during the Middle Miocene. These drier biomes were dismissed for simplification in our MMCO and MMG boundary conditions.

Still in southern Africa, north of the "tropical broadleaf evergreen forest" line, a region of "warm mixed forest" was assigned. Wolfe (1985) suggests similar vegetation patterns for that region and for southeast Australia during the Early Miocene. Assuming those two regions kept similar vegetation patterns also during the Middle Miocene, "warm mixed forest", the biome set for southeast Australia in the current MMCO and MMG reconstructions, was also assigned to that region.

The remaining areas of Africa and the Arabian Peninsula were assigned "tropical broadleaf evergreen forest", although we are aware that this is probably too broad for a characterization, as drier tropical biomes were also present. Wolfe (1985) suggests that tropical rain forest ("tropical broadleaf evergreen forest") and other drier tropical biomes populated that region during the Early Miocene. Pound et al. (2012) show the occurrence of tropical evergreen broadleaf forest ("tropical broadleaf evergreen forest") in equatorial Africa during the Middle Miocene, although combined with drier tropical biomes like tropical deciduous broadleaf forest and woodland ("tropical broadleaf deciduous forest") or tropical savanna ("savanna"). On the Arabian Peninsula, a single site indicates tropical deciduous broadleaf forest and woodland ("tropical broadleaf deciduous forest") existed in that area during the Langhian (Pound et al., 2012). These drier tropical biomes were dismissed for simplification in our boundary conditions.

\section{A6 North America and Greenland}

During the Middle Miocene, the western North American high latitudes were populated with cool-temperate mixed forest ("cool mixed forest") (Pound et al., 2012) (Fig. 5). Evidence for the eastern North American high latitudes is missing in Pound et al. (2012). Wolfe (1985) suggests two different patterns for the eastern North American high latitudes during the Early Miocene, at $\sim 60-65^{\circ} \mathrm{N}$ and north of $\sim 65^{\circ} \mathrm{N}$, respectively. For simplification only the most northern pattern, mixed coniferous forest ("cool mixed forest"), was considered in the current MMCO and MMG reconstructions.

During the Langhian, warm-temperate evergreen broadleaf and mixed forest ("warm mixed forest") was prevalent in the western North American middle latitudes above $40^{\circ} \mathrm{N}$ (Pound et al., 2012). South of $40^{\circ} \mathrm{N}$ a drier region existed, with biomes such as temperate xerophytic shrubland ("evergreen shrub land"/"deciduous shrub land") (Pound et al., 2012) (Fig. 5). During the Serravallian, the western North American middle latitudes became more heterogeneous in terms of vegetation, an amalgam of warm-temperate evergreen broadleaf and mixed forest ("warm mixed forest") combined with other drier and/or cooler biomes (Pound et al., 2012). For simplification, the Langhian pattern was used in both MMCO and MMG reconstructions.

The Rocky Mountains were set to mixed coniferous forest ("cool mixed forest") following Wolfe (1985).

The central North American middle latitudes were assigned "warm mixed forest" in the current MMCO and MMG reconstructions based on Wolfe (1985). That region has scarce data coverage in Pound et al. (2012) (one Langhian site, two Serravallian sites). Wolfe (1985) suggests two different patterns for the central North American middle latitudes during the Early Miocene, corresponding to south and north. For the southern part, Wolfe (1985) suggests similar vegetation patterns as for southeastern Australia (assigned "warm mixed forest" here), and for the northern part, similar vegetation patterns as for the European middle latitudes (assigned "warm mixed forest" here).

However, the central North American middle latitudes were not exclusively vegetated by "warm mixed forest" during the Middle Miocene. Wolfe (1985) suggests the presence of "at least some interfluve grassland" in areas such as Nebraska during the late Middle Miocene. Moreover, Pound et al. (2012) show some evidence for the presence of temperate grassland ("cool grassland") (Langhian) and temperate deciduous broadleaf savanna ("deciduous shrub land") (Ser- 
ravallian) in the central American middle latitudes during the Middle Miocene. These biomes were, however, dismissed for simplification in our current reconstructions.

The eastern North American middle latitudes were also assigned "warm mixed forest" in the current MMCO and MMG reconstructions. Pound et al. (2012) suggest warm-temperate evergreen broadleaf and mixed forest ("warm mixed forest") existed in eastern North America between 29 and $39^{\circ} \mathrm{N}$, both during the Langhian and the Serravallian. However, outside that interval of latitude no data were available from Pound et al. (2012). Since Wolfe (1985) suggests similar vegetation patterns for the central and eastern North American middle latitudes during the Early Miocene, assuming this analogy would still be valid during the Middle Miocene, "warm mixed forest" was also applied to the east, north of $39^{\circ} \mathrm{N}$ and south of $29^{\circ} \mathrm{N}$.

No Middle Miocene data were available for Greenland from Pound et al. (2012). North Greenland was filled with mixed coniferous forest ("cool mixed forest") in our current reconstructions based on Wolfe (1985). South Greenland was assigned "warm mixed forest", given its similar latitudinal position and relative geographic proximity with Iceland, where warm-temperate evergreen broadleaf and mixed forest ("warm mixed forest") existed during the Middle Miocene according to Pound et al. (2012).

\section{A7 Central America and southern Mexico}

Central America and southern Mexico were assigned "tropical broadleaf evergreen forest" (Fig. 5). Morley (2011) suggests megathermal rain forest ("tropical broadleaf evergreen forest") populated that region in the Middle Miocene. Pound et al. (2012) suggest that the tropical evergreen broadleaf forest ("tropical broadleaf evergreen forest") coexisted with drier tropical biomes (Langhian) and with temperate biomes (Langhian and Serravallian), and proposes altitude as an explanation for the presence of temperate biomes in that region during the Middle Miocene. The drier tropical biomes and the temperate biomes were dismissed in our current $\mathrm{MMCO}$ and MMG reconstructions for simplification.

\section{A8 Northern South America}

In northern South America, the northern half and the east were filled with "tropical broadleaf evergreen forest" in our reconstructions (Fig. 5). Pound et al. (2012) suggest tropical evergreen broadleaf forest ("tropical broadleaf evergreen forest") as the main biome in that region during the Langhian and Serravallian. Nevertheless, they also show evidence for some tropical deciduous broadleaf forest and woodland ("tropical broadleaf deciduous forest") in the area during the Serravallian. Morley (2011) suggests the presence of megathermal rain forest ("tropical broadleaf evergreen forest") and monsoonal megathermal forest ("tropical broadleaf deciduous forest") in that region during the Mid- dle Miocene. The "tropical broadleaf deciduous forest" was neglected for simplification in our boundary conditions.

No data were available from Pound et al. (2012) or Morley (2011) for the southwestern part of northern South America. Within that area, the Andes were assigned "warm mixed forest" and the rest "tropical broadleaf evergreen forest". For the Early Miocene Andes, Wolfe (1985) suggests similar vegetation patterns as for the most southern part of southern South America. Since significant uplift of the Andes would have started only in the late Miocene (Ghosh et al., 2006), we considered it reasonable to assume that these regions also kept similar vegetation patterns during the Middle Miocene. In this way, "warm mixed forest", the biome set in our data for the most southern part of South America (see below), was also assigned to the Andes. Surrounding the Andes there is another area with non-tropical biomes in Wolfe's (1985) reconstruction, which was dismissed here for simplification. The rest of southwest northern South America is occupied by tropical rain forest and paratropical rain forest ("tropical broadleaf evergreen forest") in Wolfe's (1985) reconstruction.

\section{A9 Southern South America}

During the Middle Miocene, in the northwest of southern South America, there was a region covered by arid biomes such as temperate xerophytic shrubland ("evergreen shrub land"/“deciduous shrub land”) (Pound et al., 2012) (Fig. 5).

In the northeast, along the coast, a narrow belt of megathermal rain forest ("tropical broadleaf evergreen forest") was present according to Morley's (2011) Middle Miocene reconstruction.

No evidence from Pound et al. (2012) or Morley (2011) was available for the area between the arid region in the west and the "tropical broadleaf evergreen forest" in the east. East of the arid region, for the area corresponding to the Andes, Wolfe (1985) proposes similar vegetation patterns for the Early Miocene as for the most southern part of southern South America. Assuming these two areas kept similar vegetation patterns also during the Middle Miocene, "warm mixed forest", the biome set in the current MMCO and MMG reconstructions for the most southern part of southern South America (see below), was also assigned to that part of the Andes. For the region east of the Andes, for the Early Miocene, Wolfe (1985) proposes a vegetation pattern similar to that of southeast Australia. Assuming this analogy was also valid during the Middle Miocene, "warm mixed forest", the biome set in the current Middle Miocene reconstructions for southeast Australia, was assigned to that region.

The south of southern South America was filled with "warm mixed forest" in our MMCO and MMG reconstructions (Fig. 5). Pound et al. (2012) shows evidence for warmtemperate evergreen broadleaf and mixed forest ("warm mixed forest") mixed with temperate grassland ("cool grassland") south of $35^{\circ} \mathrm{S}$, and again for warm-temperate ever- 
green broadleaf and mixed forest ("warm mixed forest") at $55^{\circ} \mathrm{S}$. The temperate grassland ("cool grassland") south of $35^{\circ} \mathrm{S}$ was dismissed here for simplification. 
Supplement. The supplement related to this article is available online at: https://doi.org/10.5194/gmd-11-1607-2018-supplement.

Competing interests. The authors declare that they have no conflict of interest.

Acknowledgements. This research is part of the Marie Curie Initial Training Network Throughflow, funded by the E.U. 7th Framework Programme on Research, Technological Development and Demonstration. The CCSM3 simulations were performed on the Cray XC30/40 supercomputer of the Norddeutscher Verbund für Hoch- und Höchstleistungsrechnen (HLRN). We are particularly grateful to Robert Hall, Nicholas Herold, David Pollard, and Matthew Pound for their contributions in the assemblage of boundary conditions, with further acknowledgement going to Lydie Dupont, Sandra Passchier, and Matthew Huber. We are grateful to Gary Strand, Sam Levis, Esther Brady, Stephen Yeager, and in particular to Nan Rosenbloom (NCAR) for their help with the model setup procedure. A very special thanks goes to Gabriel Gaus and Lars Nerger (HLRN) for their support in the execution of the model runs. Thanks also to Andreas Manschke for the IT support, to Ute Merkel and Gerlinde Jung for sharing their expertise in CCSM3, to Hanno Keil for his introduction to ArcGIS, and to Alexandra-Jane Henrot and Petra Langebroek for their constructive reviews that helped improve the manuscript. We are also grateful to the Throughflow Network, and the Bremen International Graduate School for Marine Sciences GLOMAR.

The article processing charges for this open-access publication were covered by the University of Bremen.

Edited by: Julia Hargreaves

Reviewed by: Petra Langebroek and Alexandra-Jane Henrot

\section{References}

Billups, K. and Schrag, D. P.: Paleotemperatures and ice volume of the past $27 \mathrm{Myr}$ revisited with paired $\mathrm{Mg} / \mathrm{Ca}$ and ${ }^{18} \mathrm{O} /{ }^{16} \mathrm{O}$ measurements on benthic foraminifera, Paleoceanography, 17, 1003, https://doi.org/10.1029/2000PA000567, 2002.

Billups, K. and Schrag, D. P.: Application of benthic foraminiferal $\mathrm{Mg} / \mathrm{Ca}$ ratios to questions of Cenozoic climate change, Earth Planet. Sc. Lett., 209, 181-195, https://doi.org/10.1016/S0012821X(03)00067-0, 2003.

Bonan, G. B.: A Land Surface Model (LSM Version 1.0) for Ecological, Hydrological, and Atmospheric Studies: Technical Description and User's Guide, NCAR Technical Note NCAR/TN417+STR, National Center for Atmospheric Research, Boulder, Colorado, 1-150, https://doi.org/10.5065/D6DF6P5X, 1996.

Bonan, G. B., Levis, S., Kergoat, L., and Oleson, K. W.: Landscapes as patches of plant functional types: An integrating concept for climate and ecosystem models, Global Biogeochem. Cy., 16, 1021, https://doi.org/10.1029/2000GB001360, 2002.

Collins, W. D., Bitz, C. M., Blackmon, M. L., Bonan, G. B., Bretherton, C.S., Carton, J. A., Chang, P., Doney, S. C., Hack, J. J., Henderson, T. B., Kiehl, J. T., Large, W. G., McKenna,
D. S., Santer, B. D., and Smith, R. D.: The Community Climate System Model Version 3 (CCSM3), J. Climate, 19, 2122-2143, https://doi.org/10.1175/JCLI3761.1, 2006.

De Boer, B., Van De Wal, R. S. W., Bintanja, R., Lourens, L. J., and Tuenter, E.: Cenozoic global ice-volume and temperature simulations with 1-D ice-sheet models forced by benthic $\delta^{18} \mathrm{O}$ records, Ann. Glaciol., 51, 23-33, https://doi.org/10.3189/172756410791392736, 2010.

DeConto, R. M., Pollard, D., Wilson, P. A., Paelike, H., Lear, C. H., and Pagani, M.: Thresholds for Cenozoic bipolar glaciation, Nature, 455, 652-656, https://doi.org/10.1038/nature07337, 2008.

Duque-Caro, H.: Neogene stratigraphy, paleoceanography and paleobiogeography in northwest South America and the evolution of the Panama seaway, Palaeogeogr. Palaeocl., 77, 203-234, https://doi.org/10.1016/0031-0182(90)90178-A, 1990.

Fairbanks, R. G. and Matthews, R. K.: The marine oxygen isotope record in Pleistocene coral, Barbados, West Indies, Quat. Res., 10, 181-196, https://doi.org/10.1016/0033-5894(78)90100-X, 1978.

Flower, B. P. and Kennett, J. P.: The middle Miocene climatic transition: East Antarctic ice sheet development, deep ocean circulation and global carbon cycling, Palaeogeogr. Palaeocl., 108, 537555, https://doi.org/10.1016/0031-0182(94)90251-8, 1994.

Foster, G. L., Lear, C. H., and Rae, J. W. B.: The evolution of $p \mathrm{CO}_{2}$, ice volume and climate during the middle Miocene, Earth Planet. Sc. Lett., 341-344, 243-254, https://doi.org/10.1016/j.epsl.2012.06.007, 2012.

Gasson, E., DeConto, R. M., Pollard, D., and Levy, R. H.: Dynamic Antarctic ice sheet during the early to midMiocene, P. Natl. Acad. Sci. USA, 113, 3459-3464, https://doi.org/10.1073/pnas.1516130113, 2016.

Ghosh, P., Garzione, C. N., and Eiler, J. M.: Rapid Uplift of the Altiplano Revealed Through ${ }^{13} \mathrm{C}-{ }^{18} \mathrm{O}$ Bonds in Paleosol Carbonates, Science, 311, 511-515, https://doi.org/10.1126/science.1119365, 2006.

Gordon, A. L., Giulivi, C. F., and Ilahude, A. G.: Deep topographic barriers within the Indonesian seas, Deep-Sea Res. Pt. II, 50, 2205-2228, https://doi.org/10.1016/S0967-0645(03)00053$5,2003$.

Greenop, R., Foster, G. L., Wilson, P. A., and Lear, C. H.: Middle Miocene climate instability associated with highamplitude $\mathrm{CO}_{2}$ variability, Paleoceanography, 29, 845-853, https://doi.org/10.1002/2014PA002653, 2014.

Groeneveld, J., Henderiks, J., Renema, W., McHugh, C. M., De Vleeschouwer, D., Christensen, B. A., Fulthorpe, C. S., Reuning, L., Gallagher, S. J., Bogus, K., Auer, G., Ishiwa, T., and Expedition 356 Scientists: Australian shelf sediments reveal shifts in Miocene Southern Hemisphere westerlies, Sci. Adv., 3, 1-9, https://doi.org/10.1126/sciadv.1602567, 2017.

Hall, R.: Sundaland and Wallacea: geology, plate tectonics and palaeogeography, in: Biotic Evolution and Environmental Change in Southeast Asia, edited by: Gower, D. J., Richardson, J. E., Rosen, B. R., Rueber, L., and Williams, S. T., Cambridge University Press, 32-78, 2012.

Hamon, N., Sepulchre, P., Lefebvre, V., and Ramstein, G.: The role of eastern Tethys seaway closure in the Middle Miocene Climatic Transition (ca. 14 Ma), Clim. Past, 9, 2687-2702, https://doi.org/10.5194/cp-9-2687-2013, 2013. 
Haq, B. U., Hardenbol, J., and Vail, P. R.: Chronology of Fluctuating Sea Levels Since the Triassic, Science, 235, 1156-1167, https://doi.org/10.1126/science.235.4793.1156, 1987.

Henrot, A.-J., Utescher, T., Erdei, B., Dury, M., Hamon, N., Ramstein, G., Krapp, M., Herold, N., Goldner, A., Favre, E., Munhoven, G., and François, L.: Middle Miocene climate and vegetation models and their validation with proxy data, Palaeogeogr. Palaeocl., 467, 95-119, https://doi.org/10.1016/j.palaeo.2016.05.026, 2017.

Herold, N., Seton, M., Müller, R. D., You, Y., and Huber, M.: Middle Miocene tectonic boundary conditions for use in climate models, Geochem. Geophy. Geosy., 9, Q10009, https://doi.org/10.1029/2008GC002046, 2008.

Herold, N., Müller, R., and Seton, M.: Comparing early to middle Miocene terrestrial climate simulations with geological data, Geosphere, 6, 952-961, https://doi.org/10.1130/GES00544.1, 2010

Herold, N., Huber, M., and Müller, R. D.: Modeling the miocene climatic optimum. Part I: Land and atmosphere, J. Climate, 24, 6353-6372, https://doi.org/10.1175/2011JCLI4035.1, 2011.

Herold, N., Huber, M., Müller, R. D., and Seton, M.: Modeling the Miocene climatic optimum: Ocean circulation, Paleoceanography, 27, PA1209, https://doi.org/10.1029/2010PA002041, 2012.

Holbourn, A., Kuhnt, W., Schulz, M., and Erlenkeuser, H.: Impacts of orbital forcing and atmospheric carbon dioxide on Miocene ice-sheet expansion, Nature, 438, 483-487, https://doi.org/10.1038/nature04123, 2005.

Holbourn, A., Kuhnt, W., Schulz, M., Flores, J. A., and Andersen, N.: Orbitally-paced climate evolution during the middle Miocene "Monterey" carbon-isotope excursion, Earth Planet. Sc. Lett., 261, 534-550, https://doi.org/10.1016/j.epsl.2007.07.026, 2007.

Holbourn, A., Kuhnt, W., Regenberg, M., Schulz, M., Mix, A., and Andersen, N.: Does Antarctic glaciation force migration of the tropical rain belt?, Geology, 38, 783-786, https://doi.org/10.1130/G31043.1, 2010.

John, C. M., Karner, G. D., Browning, E., Leckie, R. M., Mateo, Z., Carson, B., and Lowery, C.: Timing and magnitude of Miocene eustasy derived from the mixed siliciclastic-carbonate stratigraphic record of the northeastern Australian margin, Earth Planet. Sc. Lett., 304, 455-467, https://doi.org/10.1016/j.epsl.2011.02.013, 2011.

Jung, G., Prange, M., and Schulz, M.: Influence of topography on tropical African vegetation coverage, Clim. Dynam., 46, 25352549, https://doi.org/10.1007/s00382-015-2716-9, 2016.

Kaplan, J. O.: Geophysical Applications of Vegetation Modeling, $\mathrm{PhD}$ thesis, Lund University, Lund, 128 pp., 2001.

Kiehl, J. T., Shields, C. A., Hack, J. J., and Collins, W. D.: The Climate Sensitivity of the Community Climate System Model Version 3 (CCSM3), J. Climate, 19, 2584-2596, https://doi.org/10.1175/JCLI3747.1, 2006.

Knorr, G. and Lohmann, G.: Climate warming during Antarctic ice sheet expansion at the Middle Miocene transition, Nat. Geosci., 7, 376-381, https://doi.org/10.1038/ngeo2119, 2014.

Knorr, G., Butzin, M., Micheels, A., and Lohmann, G.: A warm Miocene climate at low atmospheric $\mathrm{CO}_{2}$ levels, Geophys. Res. Lett., 38, L20701, https://doi.org/10.1029/2011GL048873, 2011.

Kominz, M. A., Browning, J. V., Miller, K. G., Sugarman, P. J., Mizintseva, S., and Scotese, C. R.: Late Cretaceous to Miocene sea-level estimates from the New Jersey and Delaware coastal plain coreholes: An error analysis, Basin Res., 20, 211-226, https://doi.org/10.1111/j.1365-2117.2008.00354.x, 2008.

Krapp, M. and Jungclaus, J. H.: The Middle Miocene climate as modelled in an atmosphere-ocean-biosphere model, Clim. Past, 7, 1169-1188, https://doi.org/10.5194/cp-7-1169-2011, 2011.

Kürschner, W. M., Kvacek, Z., and Dilcher, D. L.: The impact of Miocene atmospheric carbon dioxide fluctuations on climate and the evolution of terrestrial ecosystems, P. Natl. Acad. Sci. USA, 105, 449-453, https://doi.org/10.1073/pnas.0708588105, 2008.

Kuhnt, W., Holbourn, A., Hall, R., Zuvela, M., and Kaese, R.: Neogene history of the Indonesian Throughflow, in: Continent-Ocean Interactions Within East Asia Marginal Seas, edited by: Clift, P., Kuhnt, W., Wang, P., and Hayes, D., Geoph. Monog. Series, 149, 299-320, https://doi.org/10.1029/149GM16, 2004.

Langebroek, P. M., Paul, A., and Schulz, M.: Antarctic ice-sheet response to atmospheric $\mathrm{CO}_{2}$ and insolation in the Middle Miocene, Clim. Past, 5, 633-646, https://doi.org/10.5194/cp-5633-2009, 2009.

Langebroek, P. M., Paul, A., and Schulz, M.: Simulating the sea level imprint on marine oxygen isotope records during the middle Miocene using an ice sheet-climate model, Paleoceanography, 25, PA4203, https://doi.org/10.1029/2008PA001704, 2010.

Laskar, J., Robutel, P., Joutel, F., Gastineau, M., Correia, A. C. M., and Levrard, B.: A long term numerical solution for the insolation quantities of the Earth, Astron. Astrophys., 428, 261-285, https://doi.org/10.1051/0004-6361:20041335, 2004.

Lear, C. H., Elderfield, H., and Wilson, P. A.: Cenozoic DeepSea Temperatures and Global Ice Volumes from $\mathrm{Mg} / \mathrm{Ca}$ in Benthic Foraminiferal Calcite, Science, 287, 269-272, https://doi.org/10.1126/science.287.5451.269, 2000.

Lear, C. H., Mawbey, E. M., and Rosenthal, Y.: Cenozoic benthic foraminiferal $\mathrm{Mg} / \mathrm{Ca}$ and $\mathrm{Li} / \mathrm{Ca}$ records: Toward unlocking temperatures and saturation states, Paleoceanography, 25, PA4125, https://doi.org/10.1029/2009PA001880, 2010.

Le Brocq, A. M., Payne, A. J., and Vieli, A.: An improved Antarctic dataset for high resolution numerical ice sheet models (ALBMAP v1), Earth Syst. Sci. Data, 2, 247-260, https://doi.org/10.5194/essd-2-247-2010, 2010.

Levy, R., Harwood, D., Florindo, F., Sangiorgi, F., Tripati, R., von Eynatten, H., Gasson, E., Kuhn, G., Tripati, A., DeConto, R., Fielding, C., Field, B., Golledge, N., McKay, R., Naish, T., Olney, M., Pollard, D., Schouten, S., Talarico, F., Warny, S., Willmott, V., Acton, G., Panter, K., Paulsen, T., Taviani, M., and SMS Science Team: Antarctic ice sheet sensitivity to atmospheric $\mathrm{CO}_{2}$ variations in the early to mid-Miocene, P. Natl. Acad. Sci. USA, 113, 3453-3458, https://doi.org/10.1073/pnas.1516030113, 2016.

Lewis, A. R., Marchant, D. R., Ashworth, A. C., Hemming, S. R., and Machlus, M. L.: Major middle Miocene global climate change: Evidence from East Antarctica and the Transantarctic Mountains, GSA Bulletin, 119, 1449-1461, https://doi.org/10.1130/B26134.1, 2007.

Miller, K. G., Fairbanks, R. G., and Mountain, G. S.: Tertiary oxygen isotope synthesis, sea level history, and continental margin erosion, Paleoceanography, 2, 1-19, https://doi.org/10.1029/PA002i001p00001, 1987.

Montes, C., Cardona, A., McFadden, R., Moron, S. E., Silva, C. A., Restrepo-Moreno, S., Ramirez, D. A., Hoyos, N., Wilson, J., Farris, D., Bayona, G. A., Jaramillo, C. A., Valencia, V., Bryan, J., 
and Flores, J. A.: Evidence for middle Eocene and younger land emergence in central Panama: Implications for Isthmus closure, GSA Bulletin, 124, 780-799, https://doi.org/10.1130/B30528.1, 2012.

Morley, R. J.: Cretaceous and Tertiary climate change and the past distribution of megathermal rainforests, in: Tropical Rainforest Responses to Climatic Change, edited by: Bush, M., Flenley, J., and Gosling, W., Springer Praxis Books, Berlin, Heidelberg, 134, 2011.

Oerlemans, J.: Correcting the Cenozoic $\delta^{18} \mathrm{O}$ deep-sea temperature record for Antarctic ice volume, Palaeogeogr. Palaeocl., 208, 195-205, https://doi.org/10.1016/j.palaeo.2004.03.004, 2004.

Otto-Bliesner, B. L., Tomas, R., Brady, E. C., Ammann, C., Kothavala, Z., and Clauzet, G.: Climate sensitivity of moderate and low resolution versions of CCSM3 to preindustrial forcings, J. Climate, 19, 2567-2583, https://doi.org/10.1175/JCLI3754.1, 2006.

Pagani, M., Zachos, J. C., Freeman, K. H., Tipple, B., and Bohaty, S.: Marked Decline in Atmospheric Carbon Dioxide Concentrations During the Paleogene, Science, 309, 600-603, https://doi.org/10.1126/science.1110063, 2005.

Pearson, P. N. and Palmer, M. R.: Atmospheric carbon dioxide concentrations over the past 60 million years, Nature, 406, 695-699, https://doi.org/10.1038/35021000, 2000.

Pollard, D.: A retrospective look at coupled ice sheetclimate modeling, Clim. Change, 100, 173-194, https://doi.org/10.1007/s10584-010-9830-9, 2010.

Pollard, D. and DeConto, R. M.: Description of a hybrid ice sheetshelf model, and application to Antarctica, Geosci. Model Dev., 5, 1273-1295, https://doi.org/10.5194/gmd-5-1273-2012, 2012.

Pound, M. J., Haywood, A. M., Salzmann, U., and Riding, J. B.: Global vegetation dynamics and latitudinal temperature gradients during the Mid to Late Miocene (15.97-5.33 Ma), Earth-Sci. Rev., 112, 1-22, https://doi.org/10.1016/j.earscirev.2012.02.005, 2012.

Ramstein, G., Fluteau, F., Besse, J., and Joussaume, S.: Effect of orogeny, plate motion and land-sea distribution on Eurasian climate change over the past 30 million years, Nature, 386, 788795, https://doi.org/10.1038/386788a0, 1997.

Retallack, G. J.: Refining a pedogenic-carbonate $\mathrm{CO}_{2}$ paleobarometer to quantify a middle Miocene greenhouse spike, Palaeogeogr. Palaeocl., 281, 57-65, https://doi.org/10.1016/j.palaeo.2009.07.011, 2009.

Rögl, F.: Mediterranean and Paratethys. Facts and hypotheses of an Oligocene to Miocene paleogeography (short overview), Geol. Carpath., 50, 339-349, 1999.

Rosenbloom, N., Shields, C., Brady, E., Levis, S., and Yeager, S.: Using CCSM3 for Paleoclimate Applications, NCAR Technical Note NCAR/TN-483+STR, National Center for Atmospheric Research, Boulder, Colorado, 1-81, https://doi.org/10.5065/D69S1P09, 2011.

Shevenell, A. E., Kennett, J. P., and Lea, D. W.: Middle Miocene Southern Ocean Cooling and Antarctic Cryosphere Expansion, Science, 305, 1766-1770, https://doi.org/10.1126/science.1100061, 2004.

Shevenell, A. E., Kennett, J. P., and Lea, D. W.: Middle Miocene ice sheet dynamics, deep-sea temperatures, and carbon cycling: A Southern Ocean perspective, Geochem. Geophy. Geosy., 9, Q02006, https://doi.org/10.1029/2007GC001736, 2008.
Thiede, J., Jessen, C., Knutz, P., Kuijpers, A., Mikkelsen, N., Nørgaard-Pedersen, N., and Spielhagen, R. F.: Millions of Years of Greenland Ice Sheet History Recorded in Ocean Sediments, Polarforschung, 80, 141-159, 2011.

Tong, J. A., You, Y., Müller, R. D., and Seton, M.: Climate model sensitivity to atmospheric $\mathrm{CO}_{2}$ concentrations for the middle Miocene, Global Planet. Change, 67, 129-140, https://doi.org/10.1016/j.gloplacha.2009.02.001, 2009.

Tripati, A. K., Roberts, C. D., and Eagle, R. A.: Coupling of $\mathrm{CO}_{2}$ and Ice Sheet Stability Over Major Climate Transitions of the Last 20 Million Years, Science, 326, 1394-1397, https://doi.org/10.1126/science.1178296, 2009.

Vaughan, D. G., Comiso, J. C., Allison, I., Carrasco, J., Kaser, G., Kwok, R., Mote, P., Murray, T., Paul, F., Ren, J., Rignot, E., Solomina, O., Steffen, K., and Zhang, T.: Observations: Cryosphere, in: Climate Change 2013: The Physical Science Basis, Contribution of Working Group I to the Fifth Assessment Report of the Intergovernmental Panel on Climate Change, edited by: Stocker, T. F., Qin, D., Plattner, G. K., Tignor, M., Allen, S. K., Boschung, J., Nauels, A., Xia, Y., Bex, V., and Midgley, P. M., Cambridge University Press, Cambridge, UK, New York, NY, USA, 317-382, 2013.

Wolfe, J. A.: Temperature parameters of humid to mesic forests of Eastern Asia and relation to forests of other regions of the Northern Hemisphere and Australasia, U.S. Geological Survey professional paper, 1106, 1-37, 1979.

Wolfe, J. A.: Distribution of major vegetational types during the Tertiary, in: The carbon cycle and atmospheric $\mathrm{CO}_{2}$ : natural variations Archean to present, edited by: Sundquist, E. T. and Broecker, W. S., American Geophysical Union Monograph, 32, 357-375, https://doi.org/10.1029/GM032p0357, 1985.

You, Y., Huber, M., Müller, R. D., Poulsen, C. J., and Ribbe, J.: Simulation of the middle miocene climate optimum, Geophys. Res. Lett., 36, L04702, https://doi.org/10.1029/2008GL036571, 2009.

Zachos, J., Pagani, M., Sloan, L., Thomas, E., and Billups, K.: Trends, Rhythms, and Aberrations in Global Climate 65 Ma to Present, Science, 292, 686-693, https://doi.org/10.1126/science.1059412, 2001.

Zachos, J. C., Dickens, G. R., and Zeebe, R. E.: An early Cenozoic perspective on greenhouse warming and carbon-cycle dynamics, Nature, 451, 279-283, https://doi.org/10.1038/nature06588, 2008.

Zhang, Y. G., Pagani, M., Liu, Z., Bohaty, S. M., and DeConto, R.: A 40-million-year history of atmospheric $\mathrm{CO}_{2}$, Philos. T. Roy. Soc. A, 371, 20130096, https://doi.org/10.1098/rsta.2013.0096, 2013. 